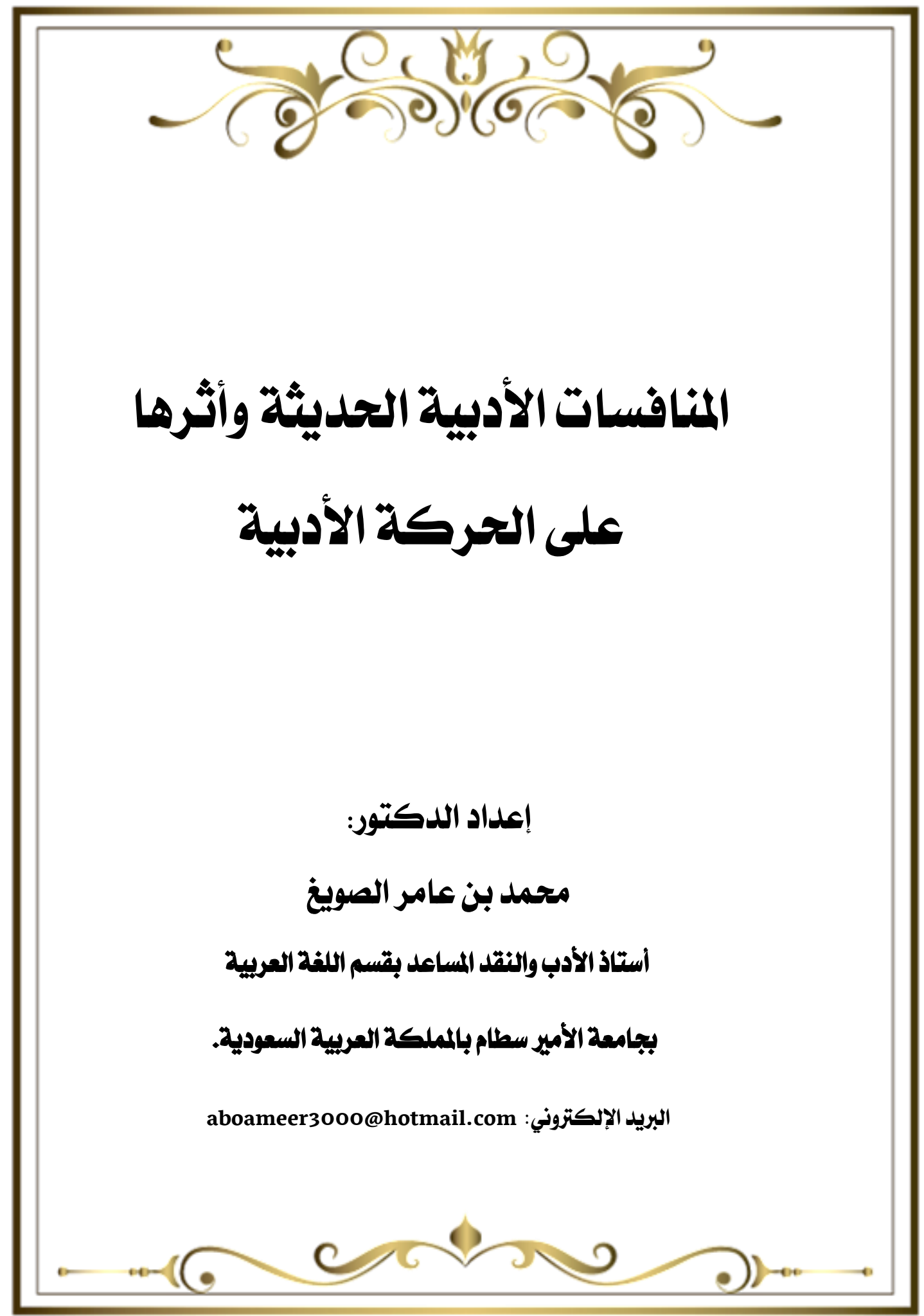




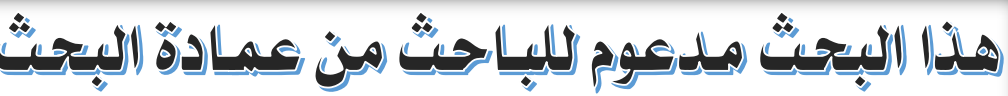

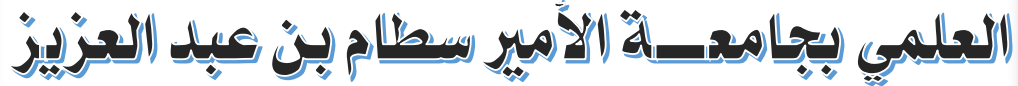

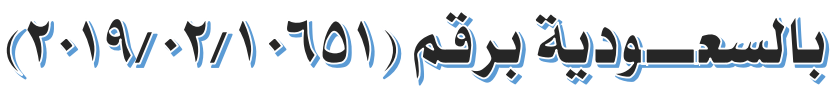

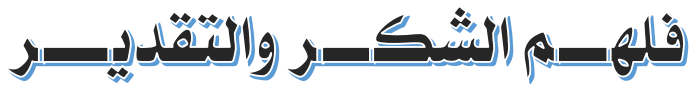




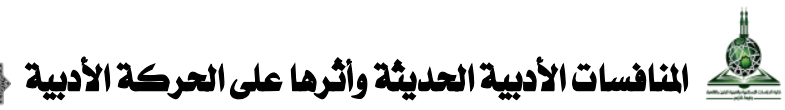
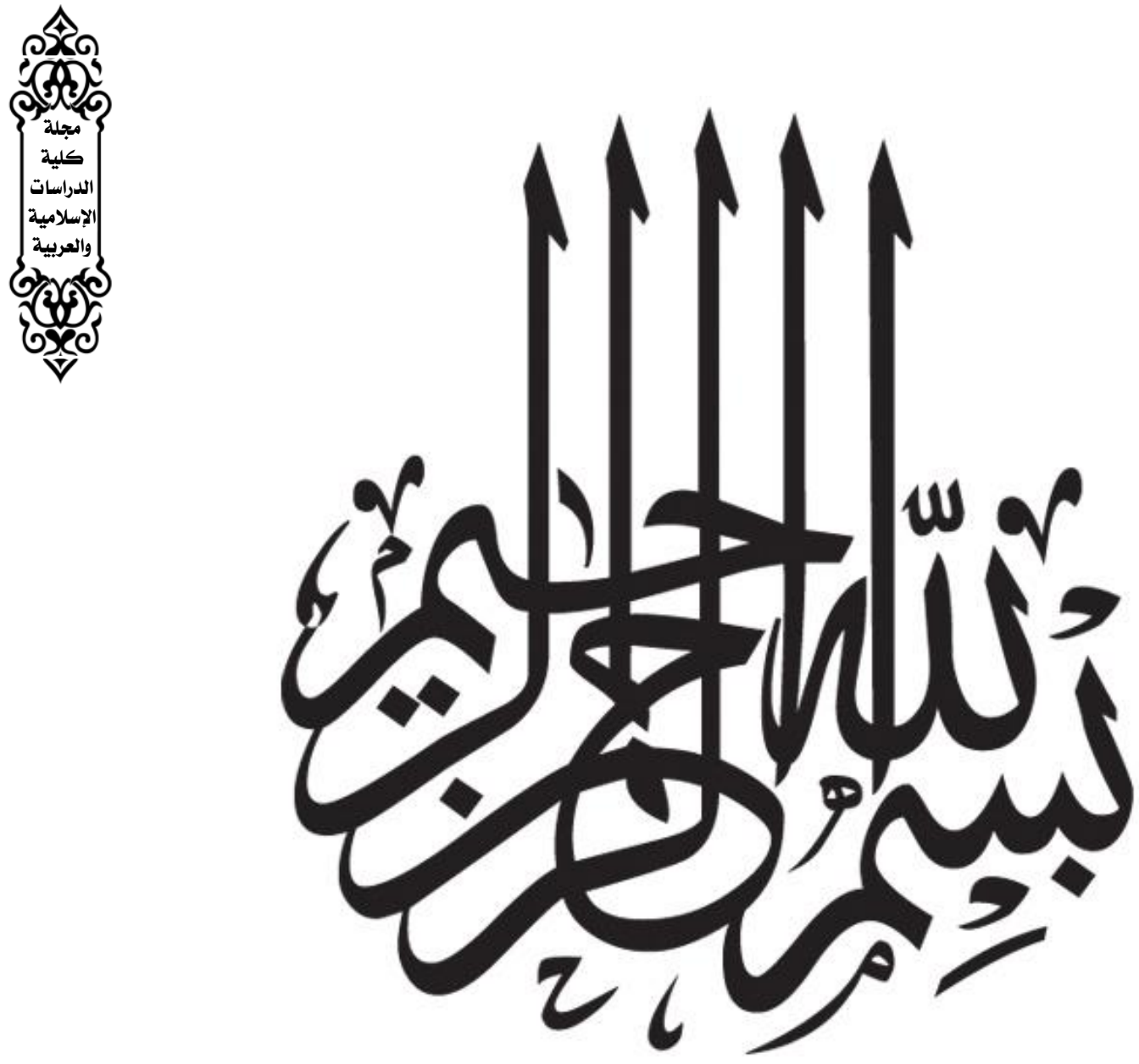
المجلد السابع والثلاثون إصدار ديسمبر 19.rم م

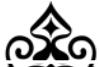

(ी)

مجلدئ

الدئية

الإسلامية

والعربية

ons

Эనec 


\section{المالخ صـ}

يتناول البحث المنافسـات الأدبية الحديثة عارضـا بعض نماذجها، ذاكرا أبرز ملاحظاتها النقدية التي حالت دون تأثيرها، خاتما بأنموذج فريد معاصـر للمنافسـات الأدبية وهو (أمير الشعبراء). ويهدف البحث إلى التعريف بأبرز المنافسـات الأدبية الحديثة، وأبرز الملاحظات النقدية التي عليها، كما يهدف إلى إبراز منافسـة (أمير الشـعراء) التي أسـهمت إسـهاما لا نظير له في العصر الحديث. وكان من أهم النتائج: أن اللغة لا تستغني عن إحياء التنافس الأدبي، وقد وجد جليا في العصور الأولى التي ازدهرت فيها اللغة، وأن العلل النقدية التي لازمت أكثر المنافسات الحديثة داخلية يمكن تجاوزها، وأن ثمَّ عناصر قوة لم تعتنِ بها هذه المنافسات. وأهم التوصيات: إقامة المنافسات في الألوان الأدبية الحديثة لا سيما ما يتعلق بمواقع التواصل الاجتماعي، مع ضرورة التواصـل المثمر بين الناقد والمتنافس، ورصـــ الحوافز المجزية لدفع ازدهار الحركة الأدبية والنقدية عموما وعلى المشاركين خصوصا. الكلمات المفتاحية: المنافسات، الأسواق الأدبية، أمير الشعراء. 


\section{Modern Literary Contests and their}

\section{Impact on the Literary Movement}

By: Mohammed Bin Amer Al-Soweigh

Assistant Professor of Literature and Criticism

Department of Arabic

Prince Sattam University

Kingdom of Saudi Arabia

E,mail:aboameer3000@hotmail.com

\section{Abstract}

This research handles modern literary contests through examining some examples, referring to the most outstanding literary observations which have not prevented their influence and concluding by a modern unique example of these literary contests; that of (the Poet Laureate). The research aims at defining the most eminent modern literary contests and the prominent critical observations related to them. The research also highlights the contest of the (poet Laureate) which has an unprecedented contribution in the modern age. One of the most important findings of this research is that language does not dispense with rekindling literary competition and that had been evident in the early ages where language flourished. In addition, the critical weaknesses related to a great deal of modern literary contests are just internal and can be handled since such contests have not paid attention to their strengths. The research has also recommended setting up contests in modern literary genres especially those related to social media. There should also be a direct and fruitful contact in between the critic and the competitor as well as prescribing rewarding prizes so as to encourage the literary and critical movement forwards together with the participants.

Key words: contests, literary contests, Poet Laureate. 


$$
\text { بسماللهالرحن الرحيم }
$$

مقدمة:

الحمد لله رب العالمين والصلاة والسلام على أشرف الأنبياء والمرسلين.. أما بعد فإن اللغة العربية في العصــر الحاضــر تعاني من ضــف ظاهر لاسـيما في مسـتوى التطبيق والممارسـة، إذا صـارت اللهجات الدارجة لكل شعب وبلد اللسـان الناطق، وانحسر حضسور الفصيح في المشاهد الاجتماعية، حتى غدا مقتصرا على وسائل الإعلام وعند بعض المثقفين. وأمام هذا الضعف الشديد صار من الواجب على كل مهتم باللغة أن يشعر بمسؤوليته وأن يكون له إسهام يرفع به من شأن اللغة حتى تستردَ عافيتهاوتعود إلى المشهد الحضاري الذي كان لها من قبل. وتتعدد الوسائل التي تخدم اللغة العربية، ومن أميزها في العصر الحديث المنافسات الحديثة، إذ حضــرت اللغة العربية حضـورا بارزا في منافسـات ثقافية يشـترك فيها نخب من أنحاء شـتى، يتنافسون في ألوان من القول وأجناس من الأدب ما بين شعر ونثر. ولا شـك أن لهذا المســابقات الأثرً البين في إعادة شـيء من بريق اللغة والاســتمتاع بجمالها وحسـن بيانها، كما أنها أسـهمت من طريق آخر باكتثــاف كثير من أهل المواهب الأدبية بل أسهمت في تنميتها بالنقد والتوجيه. ولا يقتصر اثثر هذه المنافسات الأدبية على المشاركين فيها بل يمتد إلى الجماهير المتذوقة التي تعنى بالأدب، وتسهم في الرقي بإنتاج المشاركين من خلال حضورهم المباشر وتفاعلهم الذي يرجع صـداه إلى الأديب نفسـه، وربما اتسعت دائرة التأثير فشـملت أقطاراً بعيدة من خلال نقل فعاليات هذه المنافسات الأدبية عن طريق أجهزة الإعلام ووسائل التواصل. وقد وصـل عدد المشـاهدات لحلقة واحدة في إحدى المنافسـات الأدبية إلى أكثر من مائة ألف مشاهدة( ) ، وهذا دليل على تفاعل الناس وحبهم للغتهم وتذوقهم لها . ( (1) وهذا في إحدى حلقات المنافسة الأدبية الشهيرة (أمير الشعراء) التي سيأتي الحديث عنها لاحقا. 
ويتصـل بهذه المشـاهدات تعليقات أدبية ونقدية ينتفع بها قائل النص ومتلقيه؛ لأن هذه البرامج التي تذاع فيها المنافسات تخصص مساحاتٍ للتعليق من قبل المشاهدين، وهذه التعليقات تزيد من دائرة التفاعل الأدبي الذي بدأ من ميدان السـباق ووصـل بعد ذلك إلى كل مهتم بالأدب

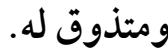
وهذه المنافسـات الأدبية جديرة بالدراسـة والتأمل والتقويم، حتى يقوي ســاعدها ويتضــاعف

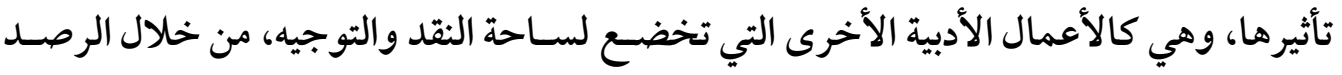
والملاحظة لهذه المنافسـات الأدبية، التي تتشـكل من عناصــر متآزرة تبدأ من لجان الإعداد والتنسيق حتى لجان النقد والحكم.

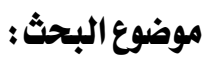

من خلال ما سـبق تبين موضسوع البحث، فإن هذا البحث يتلخص في دراسـة حال المنافسـات الأدبيـة الحـديثـة ودورهـا المحـدود في دفع عجلـة التقـدم الأدبي والنقـدي، واسـتخراج أبرز الملاحظات النقدية التي حسرت ضوء التأثير عنها، مع إبراز نموذج متميز للمنافسات الحديثة،

$$
\text { والصفات التي بها تبو أت هذه المنزلة. }
$$

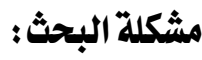

تكمن مشـكلة البحث في وجود عدد كبير من المنافسـات الأدبية الحديثة التي لم يظهر لها الأثر البين على السـاحة الأدبية والنقدية، فإلى أي شسيء يرجع ذلك؟ وكيف نسـهـم في الارتقاء بها؟ وهل ثمَّ نموذج حديث للمنافسات الأدبية يمكن أن يفاد منه؟ أهمية البحث وسبب اختياره :

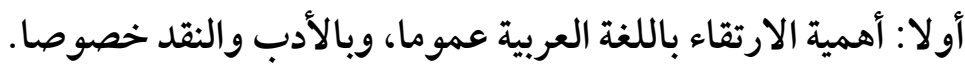
ثانيا: انعدام المنافسات الأدبية المؤثرة على مستوى العالم العربي.

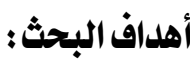
أولا: إبراز أثر التنافس الأدبي على الحركة العلمية والثقافية. ثانيا: الوقوف على أبرز الملاحظات النقدية للمنافسات الأدبية الحديثة لتجازوها والارتقاء بها. 
ثالثا: عرض نموذج متميز للمنافسات الأدبية الحديثة، وبيان وجه ذلك. منهج البحث: وقد تتبعت في هذه الدراسة المنهج الاستقرائي للوقوف على هذه المنافسات الأدبية التي تناثرت رقعتها الجغر افية، فنـملت كل بلاد العالم العربي، كما تنوعت الفنون الأدبية التي يتنافس عليها

المثـاركون، ورأيت أن بعضــها اقتصـر على جنس أدبي واحد، وبعضــها نوع - وهو الأكثر وطرق أكثر من جنس، وقـد أفـاد المنهج الاسـتقر ائي في الوقوف أولا على هـذه المنافســات الأدبية، ثم دراستها وتقويمها. حلود البحث: يتناول البحث المنافسات الأدبية الحديثة من بقع جغر افية متنوعة من العالم العربي بهدف رصد الملاحظات النقدية لتجاوزها، مع إبراز الوجه المشـرق لإحدى هذه المنافسـات، وبيان أمارات التميز والطريقة التي تسير عليها المنافسة. إجراءات البحث : أبر أولا: بدأت بجولة تاريخية للمنافسات الأدبية عن العرب قديما. ثانيا: ذكرت في هذا التمهيد أثر هذه المنافسـات على الحركة الأدبية وازدهارهـا من خلال

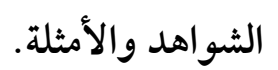
ثالثا: قسـمت البحث إلى فصـلين: تناولت في الأول المنافســات الأدبية الحديثة، وفي الفصـل الثاني: تناولت منافسة أمير الشعراء. رابعا: قسمت المنافسات الأدبية الحديثة حسب الأجناس الأدبية التي تستهدفها. خامسا: تناولت في البحث منافسات أدبية متنوعة من العالم العربي، وأبرزت ماله إضافة أو تميز عن غيره. سادسا: قارنت بين المنافسات الأدبية القديمة والحديثة، مستشهدا على ذلك بالو قائع والأحداث. سابعا: في دراستي للمنافسات أبرزت الملاحظات النقدية وأثرها على الأديب والنص.

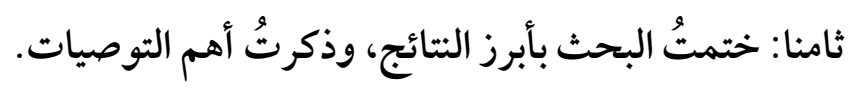


تاسعا: ذيلت البحث بفهارس للمصادر والمراجع والموضوعات.

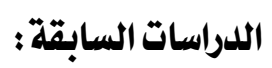

بعد البحث والدراسة لم أقف على من أفرد هذا الموضسوع بالبحث والدراسة، وثمت إشـارات نقدية وأدبية مبثوثة في كتب التراث يمكن الإفادة منها.

الجليد في الدراسة:

أولا: جمع منافســات أدبية حديثة ومتنوعة أكثرها غائب عن المشــهد الثقافي العـام لكونها حوصرت ببقعة جغر افية أو وسائل نشر بدائية. ثانيا: الربط بين المنافسات قديما عند العرب و المنافسات الحديثة، وبيان أثر ذلك على الأدب والنقد. ثالثا: بيان العلل النقدية التي لحقت هذه المنافسـات الأدبية فحالت دون تأثيرها والقيام بدورها المنشود في خدمة اللغة عموما والأديب خصوصا. خطة البحث: - ماث

وقد انتظم عقد هذه الدراسة في مقدمة وتمهيد ومبحثين وخاتمة وفهارس على النحو الآتي: التمهيد: نبذة عن المنافسات الأدبية قديمًا.

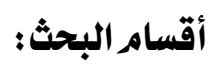
القسم الأول: المنافسات الأدبية الحديثة، وفيه مباحث: تمهيد. المبحث الأول: المنافسات ذات الجنس الأدبي الواحد. المبحث الثاني: المنافسات ذات الأجناس الأدبية المشتر كة. المبحث الثالث: نظرة ناقدة لهذه المنافسات الأدبية. القسه الثاني: (أمير الشعراء) المنافسة النموذج، وفيه مبحثان: المبحث الأول: أهداف منافسة أمير الشعراء. المبحث الثاني: شروط منافسة أمير الشعراء.

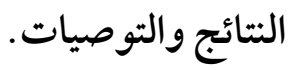




\section{المافسات الأديية الحديثة وأثرها على الحركحة الأديية}

\section{التمهيد \\ نبلة عن المنافسات الأدبية قديماً}

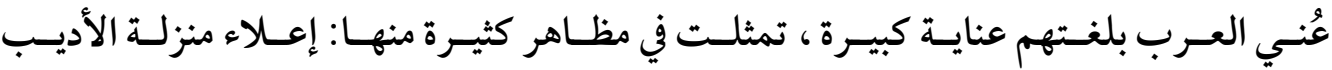

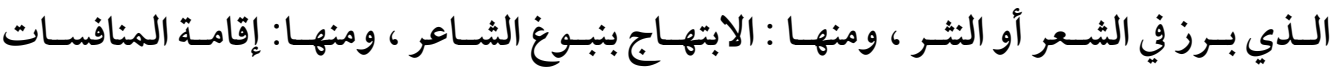

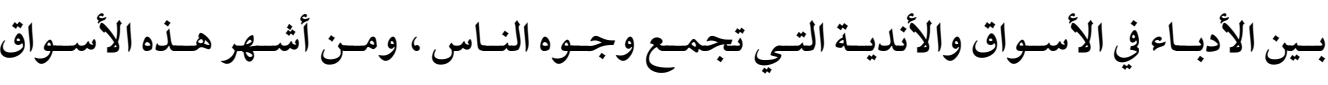
التي تقــام فيهـا المنافسـات الأدبيـة سـوق عكـاظ "الـذي كـان للشـعراء والحكـام فيـه على

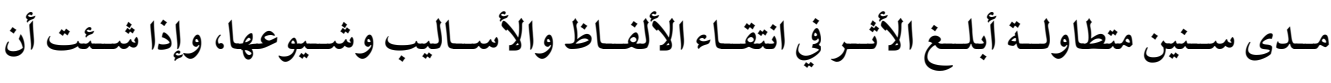
أختصــر ذلـك كلـه بكلمـة واحسدة قلـت : إن نهضـة الثـعر مدينـة للأسـواق ، بـل مدينـة

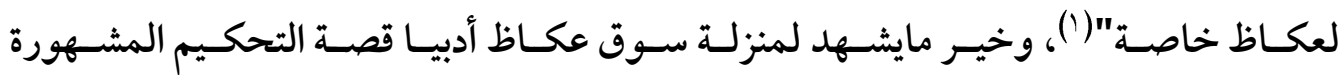

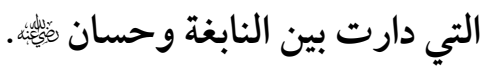

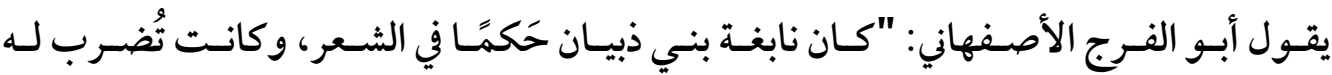

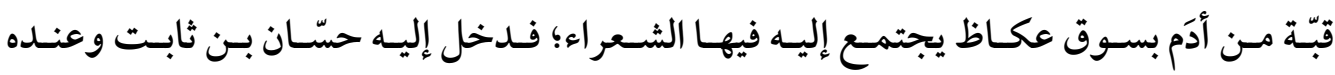
الأعشى، وكان قد أنشد الأعشى شعره. ثم حضرت الخنساء، فأنشدته قصيدتها التي مطلعها: أم ذرفـت إذ خلــت مــن أهلهــا الـدار قــــذ بعينـــــك أم بـــــالعين عـــــوَّار

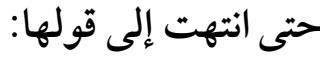

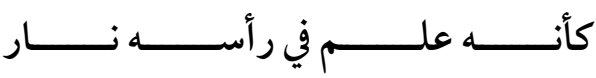

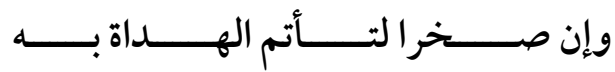

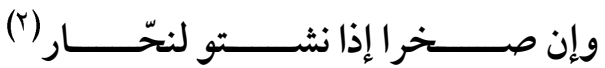

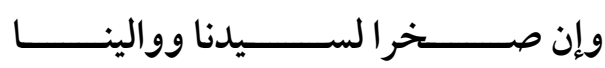

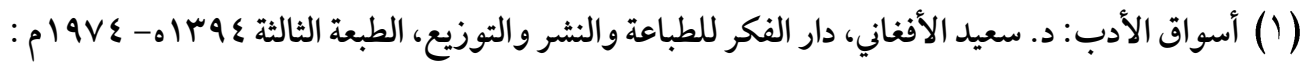
$r \cdot \Lambda \cdot n$ (Y) ديوان الخنساء اعتنى به وشرحه حمدو طماس، دار المعرفة، بيروت- لبنان، الطبعة الثانية، ه؟ اه ـ $\varepsilon r: p r \cdots \varepsilon$ 


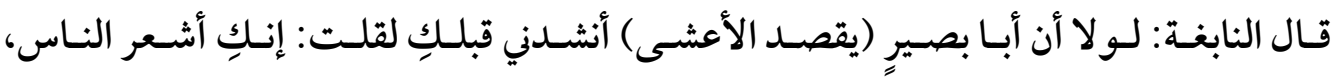

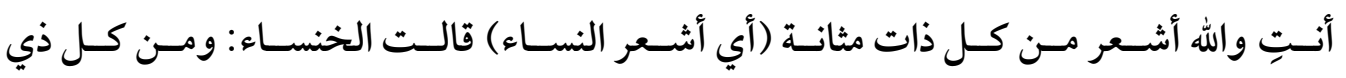
خُصيتين (كناية عن الرجال). فقال حسان: أنا والله أشعر منك ومنها قال: حيث تقول ماذا؟ قال: حيث أقول:

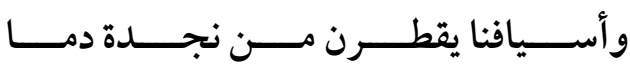
لنـا الجفنـات الغـر يلمعـن بالضـحى

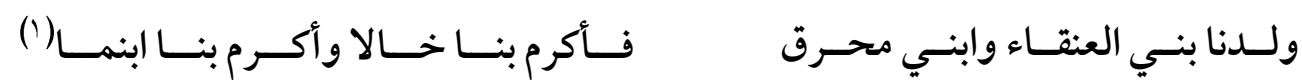

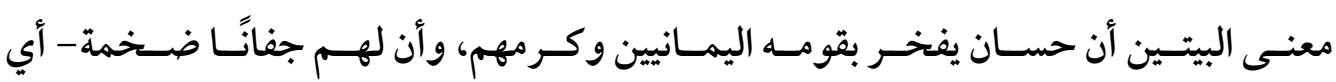

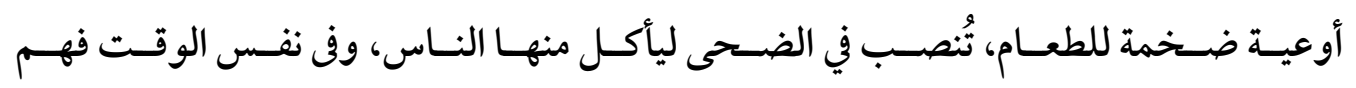

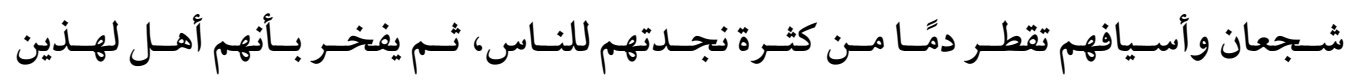

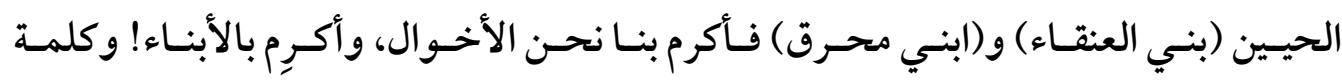
(ابنما) تعنى ابن، ويجوز زيادة (ما) فيها، قال النابغة: إنك لشاعر لو لا أنك قللت عدد جفانك، وفخرت بمن ولدت، ولم تفخر بمن ولدك.

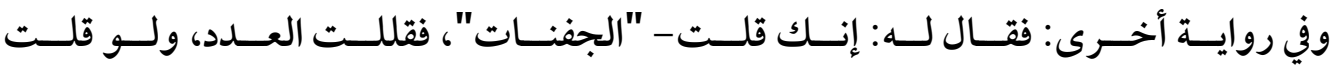

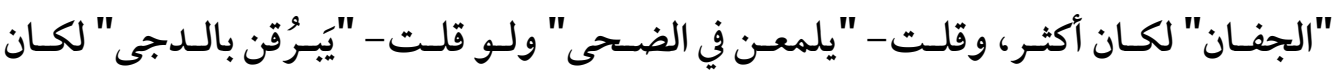

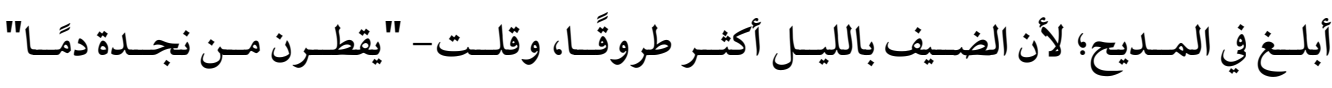

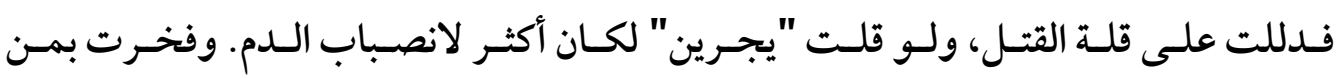
ولدت ولم تفخر بمن ولدك، فقام حسان منكسرًا منقطعًا"(؟).

( (1) ديوان حسان رضي الله عنه، تحقيق أ / عبد مهنا ، دار الكتب العلمية، الطبعة الثانية ؟ إ اهـ ـ 99 ام :

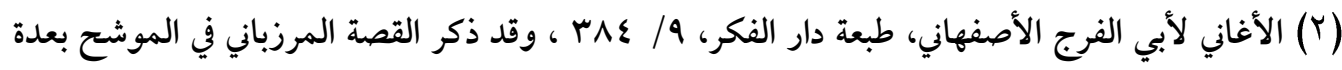
روايات تحقيق محمد حسين شمس الدين، دار الكتب العلمية-بيروت، الطبعة الأولى هـ إ اهـ - 1990 1م : 


\section{المنافسات الأديية العديثة وأثرها على العركة الأديية}

وحسين تتأمـل هـذا المشـهـ تقـف على مـدى عنايـة العـرب بلسـانهم حسين حكّمــوا أمهـرهم فيها ، وتجـد أن حسـان دفعسه تفضـيل غيـره عليه إلى أن يأتي بمـا هـو أجـود ممـا قالـه ، وهـذا

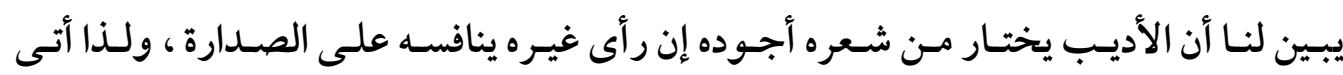
حسان بأفضل مما قاله قبل ، إلا أن النابغة استدرك عليه ثانية .

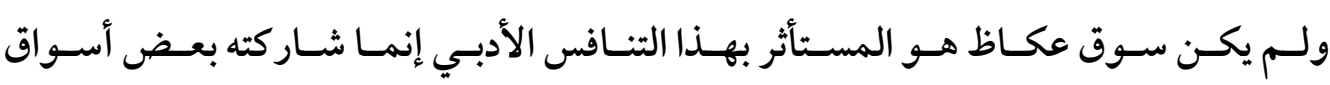
العـرب ومنتـــاتهم وإن لـم تكـن في المسـتوى الـــي وصـل إليسه سـوق عكــاظ؛ لأن سـوق عكاظ ذا جمهور واسع يقصده العرب وغيرهم من أماكن شتى.

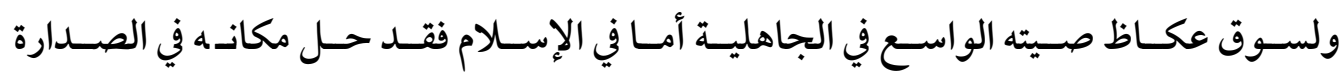

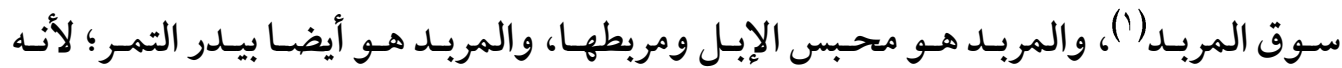
يشمس فيه، والربدة لون إلى الغبرة.(r)

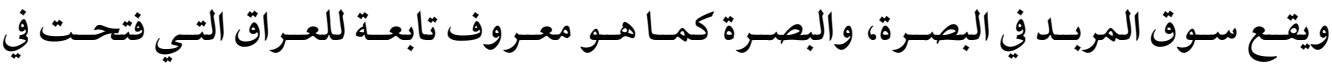

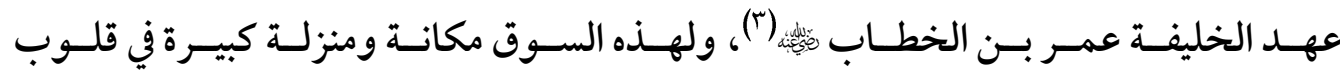

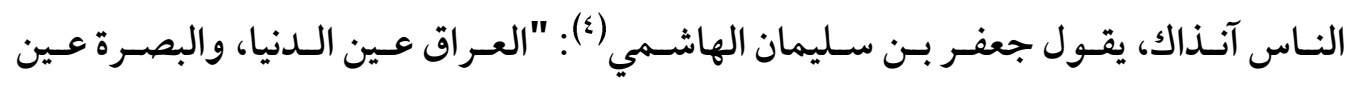
العراق، والمربد عين البصرة وداري عين المربد "(o).

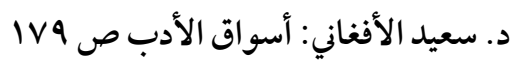

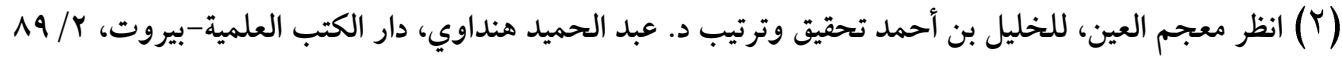

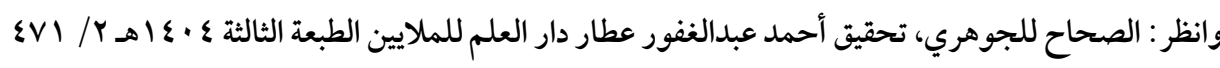

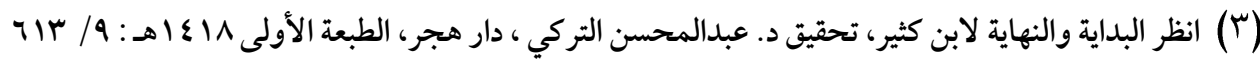

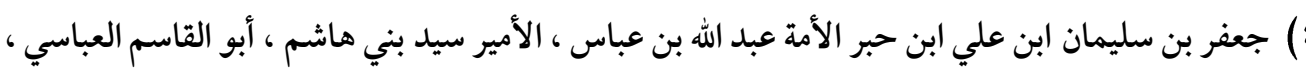
ابن عم المنصور، وكان من نبلاء الملوك جودا وبذلا وشجاعة وعلما وجلالة وسؤددا ، ولي المدينة ،

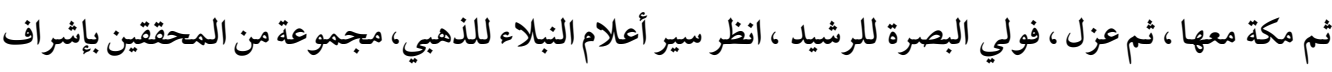

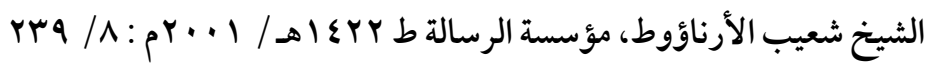

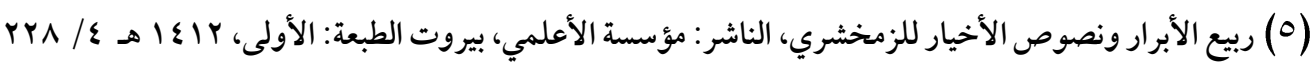


ولم تكن سوق المربد أول أمرها للشعر والأدب إنما كانت قبل ذلك سوقا للإبل فقط ، يقول ياقوت الحموي : " مربد البصرة من أشهر محالها ، وكان يكون فيه سوق الإبل قديما ثم صار محلة عظيمة سكنها الناس ، وبه كانت منافرات الشعراء "( ) ثم ذكر أن سوق المربد كان ملاصقا للبصرة ثم بان عنها فقال : " وهو الآن بائن عن البصرة نحو ثلاثة أميال، وكان ما بين ذلك كله عامراوهو الآن خراب، فصار المربد كالبلدة المنفردة وسط البرية "(() .

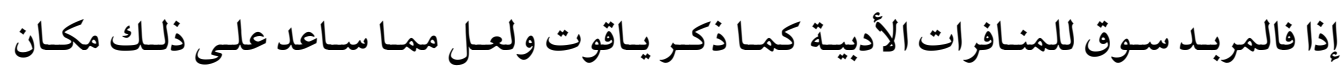
المربــد المتميـز، فهـو في رأس الجزيــرة العربيـة وعـن ميمنـة الثـام وعلسى مشـارف فـارس ،

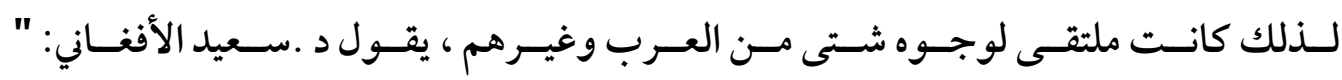

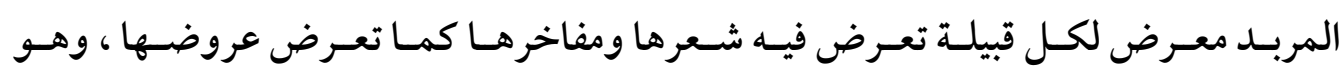
مجتمع العرب ومتحدثهم ومتنزه البصريين يؤمّه من عاف رخاوة المدن "(؟).

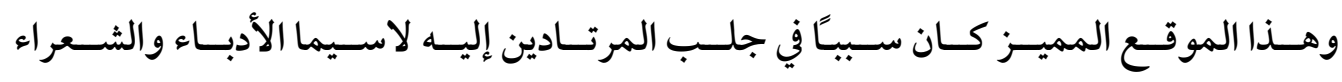
والجمـاهير المتذوقـة، ولــذا كانـت تعتقـد فيـه حلقـات الثـعر، وكانـت كـل حلقـة حريصـة

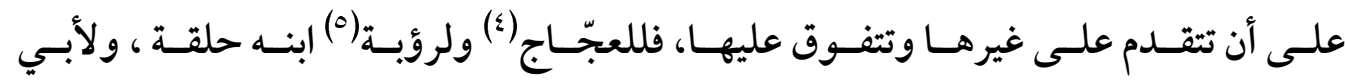

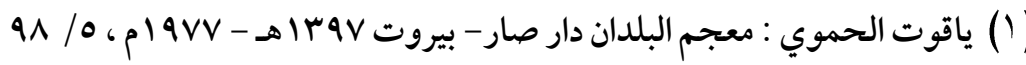

$$
\begin{aligned}
& \text { (Y) السابق نفس الصفحة }
\end{aligned}
$$

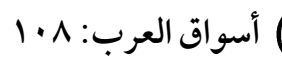

عبد الله بن رؤبة بن لبيد بن صخر السعدي التميمي أبو الشعثاءًا راجز مجيد، من الشعراء، ولد ألد ألداء

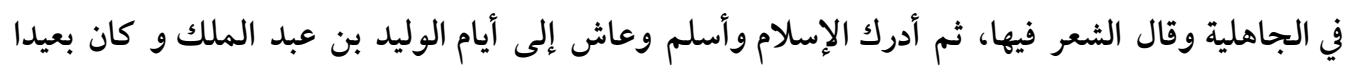

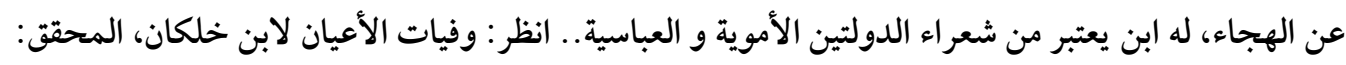

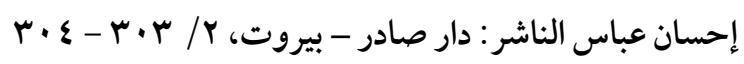

(0) رؤبة بن عبداله العجاج بن رؤبة بن لبيد بن صخر السعدي التميمي من رجاز الإسلام وفصحائهم وهو من

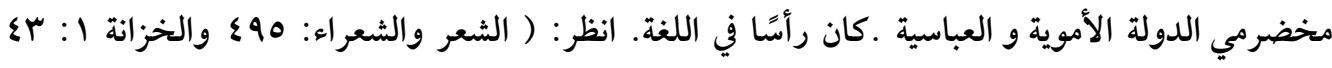

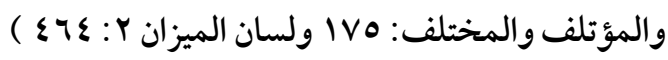


الـنجم العجلـي(') حلقـة .. وغيـرهم، وكــان للــرواة في هـذا السـوق دور في إثـعال فتيـل

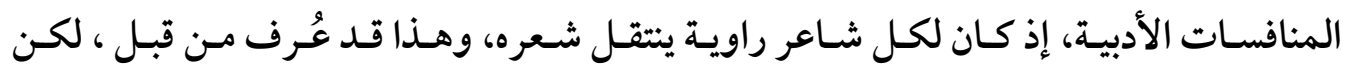
الـذي أضـافه الـرواة في هـذه السـوق أنهـم كـانوا ينقلـون مـا قالـه خصـم الشـاعر إلـى الشــاعر ليـرد عليـه ، فـإذا مـا قـال جريـر قصـيدة يهجـو فيهـا الفـرزدق ، فبإن رواة الفـرزدق يسـارعون

في نقلها إليه لينقضها ، وربما جمعتهم -أي الشاعرين - حلقة للنقائض والتهاجي (r).

وفي خضــم هذا الثنافسـات الأدبية تظهر أســاليب جديدة وطرق مبتكرة في فن القول والكتابة، و كان اللغويون حريصـين على تدوينها وكتابتها، إذ كان المربد يزدحم بأعلام اللغة والثـعر والأدب، فهذا أبو عمرو بن العلاء يسأل الأصمعي: من أين أقبلت؟ فيجيبه : جئت من المربد ، فيقول : هات ما معك ، فيقر أ عليه الأصسمعي ما كتب في ألواحه فإذا سـتة أحرف ( كلمات) لم يعرفها أبو عمرو ، فيخرج يعـدو في الدرجة ، ويقول للأصـمعي : شــمّرت في الغريـب ، أي غلبتني (r) - (ب) يقول أحمد أمين مبينا منزلة سوق المربد ودوره في إشغال فتيل المنافسات الأدبية : "كان المربد في عصـر الخلفاء الراشـدين والأمويين مركزا سـياسـيًا وأدبيًا وكان مركزاً للمهاجاة بين جرير والأخطل والفرزدق وأنتج ذلك نوعا من أقوى الثـعر الهجائي كالذي نقرؤه في النقائض، وكان لكل من هؤلاء الشعراء حلقة ينشد فيها شعره وحوله الناس يسمعون"(؛) . ومن أخبار شـعر التهاجي في سـوق المربد ما وقع بين جرير والفرزدق في خصــومه قبيلة ( بني

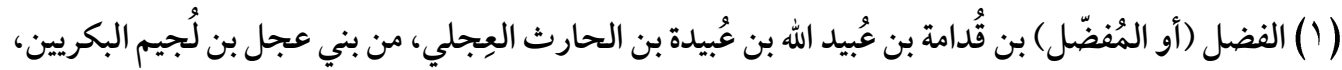

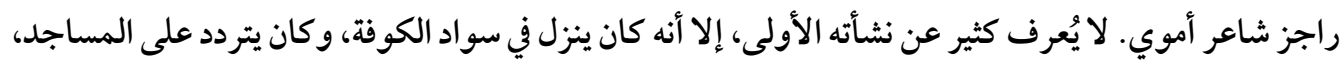

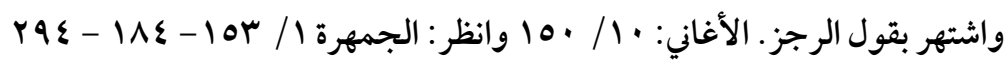

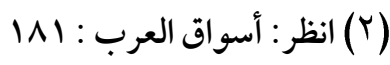

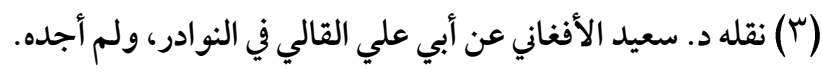

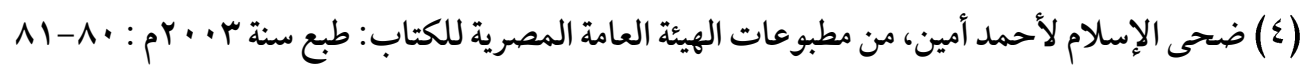




\section{المجلد السابع والثثلاثون إصدار ديسمبر 19 .rم م}

العم) وهذه القبيلة ليست من صـميم العرب ، نزلوا ببني تميم في أيام عمر بن الخطاب فأسلموا وغزوا مع المسلمين وحسن بلاؤهم فقال الناس : أنتم وإن لم تكونوا من العرب إخواننا وأهلنا وأنتم الأنصـار والإخوان وبني العم ، فلقبوا بذلك وصـاروا في جملة العرب .. حضــرت هذه القبيلة المربد وقد تواقف للهجاء جرير والفرزدق يرد هذا على ذاك ، ووراء كلٍ قبيلته وحزبهُه ، فهاج الشر واقتتلت القبيلتان: بنو يربوع قوم جرير ، وبنو مجاشع قوم الفرزدق، فأمدت بنو العم بني مجاشع وجاؤوهم وفي أيديهم الخشب فطردوا بني يربوع ، فقال جرير : من هؤلاء ؟ قالوا : بنو العم ، فقال جرير يجهوهم ويعرض بالفرزدق وأنصاره :

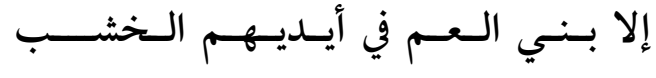

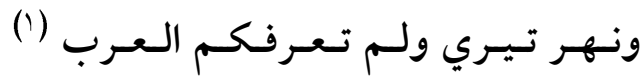

مـا لـلــــرزدق مـن عـز يـلـوذ بــه

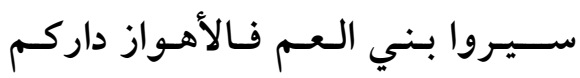

لقد كان المربد ميدانا للمسـاجلات الشعرية والتنافس الأدبي، كل يجود بما يحسن، والأنصـار الذين حول الثــاعر يذكون الفتيل، كما رأينا هنا في أنصـار جرير والفرزدق، ولم يزل شــأن الجمهور إلى اليوم ظاهر الأثر في إثارة الأديب وصقل موهبته ودفعه ليقول الأفضل، وليطرح ما سُبق إليه، ولترتقي ذائقة أنصاره إليه ومحبيه. تبين فيما سـبق حرص العرب على لغتهم نثرًا وشـعرًا ، ورأينا كيف أنهم في مجامعهم يتبارزون بالقول ويبدعون في الكلام ، حتى مُلئت كتب الأدب من أخبارهم ، فلم يغشــوا هذه المجالس والأسواق للبيع والثـراء فحسب إنما كان للغة والأدب نصيب، وربما سـاعد الجماهيرٌ في هذا التنافس الأدبي من خلال حضسورهم أو تحفيز الثـاعر على نظم بديع القصسيد ، ورأينا سـعيهم بين الثـعر اء المتخاصسمين فزادوا النار ضـر اما حتى التحمت القوافي بالقوافي ، ولم يغب علماء اللغة الكبار كالأصـمعي وأبي عبيدة عن هذه المشـاهد، بل كانوا يحضـرون المنافسـات الأدبية

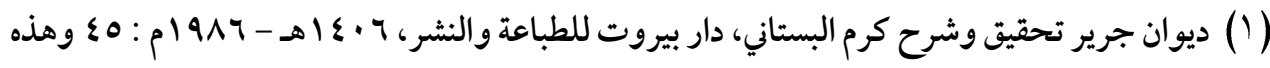
القصة ذكرها صاحب الأغاني: rov r r r 
لسجلوا كلام العرب ويعرفوا معانيه وغريبه وطريفه، وطرائق الشعراء في إبانتهم . و المنافسـات الأدبية من شــأنها أن تثري اللغة وتدفع إلى التجديد والابتكار ونظم الجياد من القصــائد والخطب وغيرها من فنون الكلام، إلا أن المنافسـات الأدبية حديثا خبت نارها، ولم يعد لها ذلك الوهج الذي كلنت عليه في العصــور الأول، وتكتنفها بعض المآخذ التي تحد من أثرها، ولإلقاء النظر عليها تأتي هذه الدراسة. 


\section{القسم الأول : المنافسات الأدبية الحلديث}

برزت مؤسسات علمية وثقافية في خدمة اللغة العربية حديثا، وحملت على عاتقها خدمة اللغة وتشجيع التتاج اللغوي لاسيما فئة الشباب، وأقامت منافساتٍ أدبية يجول في مضمارها الأدباء الناشئون، وقد تعددت الفنون الأدبية التي يُنتافس فيها، وكذلك البقع الجغر افية التي يجرى فيها

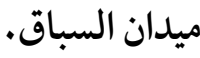

إذا تأملنا في المنافسات الأدبية الحديثة وجدناها على صورتين: نمطية تقليدية، وأخرى تجديدية إبداعية.

أما التقليدية فإن المنافسـات تتبع مسيرة الظهور مبتدئة بالإعلان مبرزة اسـم عَلَمَ ودولة، محددة اللون الأدبي الذي ســيجول الأدباء فيه، ومن المســابقات من لا تحدد لونا معينا إنما يتخير الأديب بين الأجناس: قصيدة، قصة، مسرحية، ثم يذكر في الإعلان شروط المنافسة التي غالبا ما يكون فيها حجم المشار كة (عدد الأبيات مثلا) ومن يحق له أن يشارك وكيف تُسلّم المشاركات

$$
\text { وآخر موعد لاستلام هذه المشاركات من الأدباء. }
$$

وبعد هذا تتولى لجنة المنافسـة اسـتقبال المشـاركات والنظر فيها وتقييمها ثم إعلان الفائزين وإقامة حفل لتكريمهم، هذه الصـبغة هي غالب ما عليه المنافسـات الأدبية حديثا في العالم

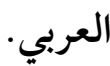
إذا فالتقليدية متشــابهة الثــكل والمضــمون، تسـير وفق منظومة واحدة، لاترى فيها تميزا، ولايفرق بينها إلا الأسـماء، وهي الأكثر انتشـارا في العالم العربي ، وهي مغايرة لما عليه العرب الأوائل في منافساتهم، إذ يجد الناظر في منافراتهم ومنافسـاتهم شيئًا من الحماس والمشـاركة ، فإن المجالس الأدبية تعقد لكل شـاعر كجرير والفرزدق ، ثم يحضـر أنصـار الشـاعر وخصسومه ليسمعوا منه ، فإن سمعوا هجاء في خصمه نقلوا ما قاله إلى خصمه ليسمعوا منه الرد ثم يعودوا به إلى الشاعر الأول ، وهكذا دواليك . 


\section{المافسات الأديية العديثة وأثرها على العركة الأديية}

هذه الصورة الأولى من المنافسات الأدبية - كما أسلفت - ليس فيها نزعة التجديد الذي يلهب حماس الشـعراء ويذكي قرائحهم، ونرى كثير ا منها في منافسـات عالمنا العربي الأدبية ، ولذا تخرج بصورة باهتة عديمة الأثر . المبحث الأول : المنافسات ذات الجنس الأدبي الواحل : وقد حاز الشعر النصيب الأوفى، ومن هذه المنافسات:

أ - جائزة جمعية علي بن غذاهم (') للشعر العربي بتونس، وقد وضعت هذه المنافسات شرطا للاشتر اك فيها كان أعجبها أن يشارك المترشح بما يوازي مجموعة شعرية لا تقل عن حجم كتاب من مائة وعشرين صفحة.

وهذا الشرط سيحجب كثير امن المشاركات ويحرم كثيرا من المتنافسين، والإبداع الشعري لا يقف على الكم، وكأنها منافسـة في التأليف لا في الأدب، وربما هذا المقصـــ؛ لأنهم جعلوا الجائزة أن يطبع الديوان فقط، وفي تقديري ليس ذا بكاف؛ لأن يُقدم الأدباء على المشـاركة، بل إنّ أي أديب مهما ضعفت بضاعته سيجد دارا تطبع له، وتنشر شعره (؟). ب -جائزة الشاعر أسامة الدناصوري(َ) : وتمتاز هذه المنافسة بأن خصصـت مجال المشـاركات فيها على قصـيدة الثثر ، ولم تقيد بلدا ولا عمر اللمشـاركين ، إلا أن المقابل المادي كما سـبق طبع الديوان فحسب ، وهذا لا يعد مشجعَّا للإبداع والمشاركة(؛) ج -جائزة الملتقى للقصة القصيرة العربية؛ وهي جائزة سنوية تقبل فيها المشاركات القصصية، وتقبل فيها المشار كة بالترشيح، وذلك أن يرشح الناشر مجموعة قصصية بموافقة المؤلف، وهذا

(1) علي بن محمد بن غذاهم الماجري من عرش أولاد مساهل من قبيلة ماجر البربرية ولد سنة ؟ ال أم وتوفي

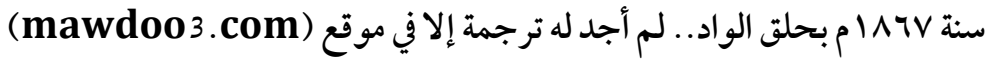

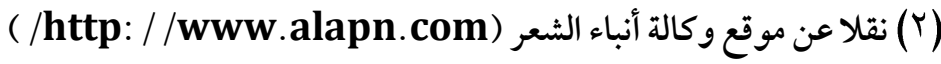

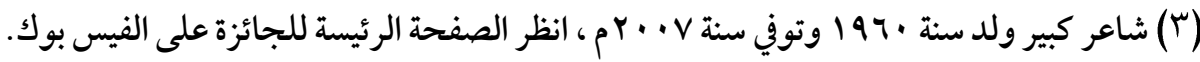

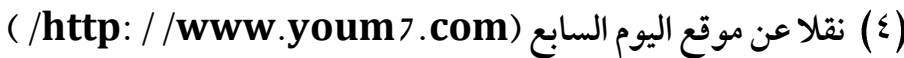


ما تمتاز به هذه المنافسة ، إذ فعّلت دور الناشرين في مجال الأدب ؛ لأنهم الوعاء الذي يقدم الأدب لمتذوقيه، ولذا فإن على الناشر أن يتخير من ينشر له لا أن ينشر لكل أحد . ويشتر في هذه المنافسـة أن يكون القاص قد أمضى سـنتين في مجال الكتابة القصصية ويثبت هذا بمنثــوراته السـابقة المقيدة تاريخيا، وهذا الشــــ يضـمن عدم دخول المبتدئين الذين لم

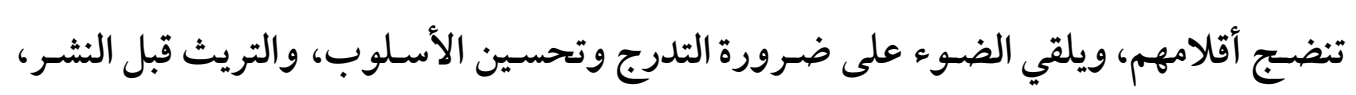
كما أن المنافسة تكتسي بهذا الشـرط قوة في مشـار كاتها، وتوفير اللوقت والجهد في قراءة بعض النصوص التي لا ترتقي أن تكون أدبـً (') . د - جائزة البيت الثقافي للكتابة القصة القصيرة ( الومضة ) وهي القصة القصيرة جداً، وتمتاز هذه المنافسة بتحفيز الأقلام للإسهام في هذا اللون الأدبي بالغ الأثر، الذي أغفلته كثير من المنافسات

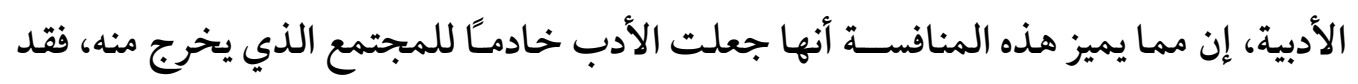
اشـترطت أمانة المنافسـة أن تكون القصـة محاكية لواقع وطموح المجتمع العراقي (r) ؛ لأن للأدب رسالةً سامية ينبغي أن تُفعّل، ولأن الإغراق في الذاتية يجعل النص حبسيا في صدر قائله، وإن نشـره لا يجد له ذلك الصـدى الكبير، ويمكن أن يجمع الأديب في ومضسته و أدبه همسة من ذاته يجد كثيرًا من أبناء مجتمعه يشار كه فيها، فتكون المشار كة ذاتية من جهة، مجتمعية من جهة ولته

$$
\text { أخرى، إذ الأدب تعبير عن مشاعر صادقة لا تستعار لإرضاء الآخرين . }
$$

وهي التي جمعت أكثر من لون أدبي، يختار منها المشارك ما يشاء، ومن أبرز هذه المنافسات:

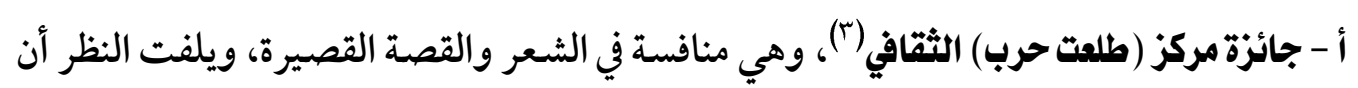

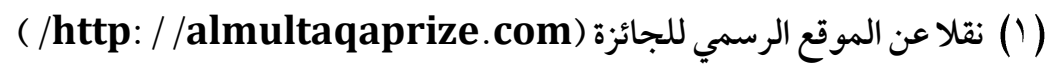

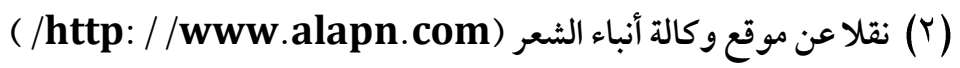
(Y) محمد طلعت باشا ابن حسن بن محمد حرب: زعيم مصر الاقتصادي، وكاتب باحث، ألف كتبا ورسائل،

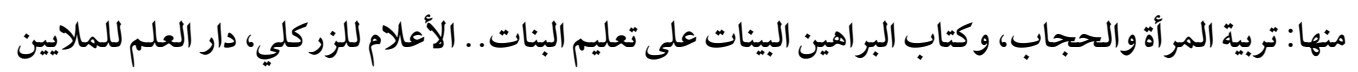


المنافسة لم تلتزم بالشـعر الفصيح إنما جعلت الاختيار للمشـاركين، فلهم أن يختاروا الفصسيح أو العامي، ولاريب أن الثـعر العامي وإن كان له أنصـاره ومحبوه فإنه لا يرتقي إلى أن يكون قسيمًا للشعر الفصيح الذي هو ميراث الأدباء جيلا بعد جيل، ثم إن المؤمّل من هذه المنافسات أن تكون دافعًا للإبداع الأدبي الفصيح لا أن تُزاحم بالأدب العامي الذي لا يتواءم مع روح اللغة

وجمال البيان(') - (') (1)

ب -جائزةقسوق عكاظ(؟) : في مجالي الشعر والقصة القصيرة، وتقام هذه المنافسة سنويـًا تزامنا مع الاحتفال بهذا السوق الذي له مكانة تاريخية من قبل الإسلام، ولا تقتصر المشاركات على من هم داخل المملكة إنما فتح المجال أمام الراغبين، وتعرض المشــاركات على لجـان علمية متخصصة ثم يرشح فائز واحد في الشعر، وآخر في القصة ويدعى لحضور فعاليات سوق عكاظ التي تستمر أياما تطرح فيها ألوان من الأدب شعره ونثره وفعاليات ثقافية وفكرية. وهذه المنافسـة على جمال فكرتها وتميز تنظيمها لا يشـرف بالفوز بها إلا مشـار كان اثنان فقط، ولو أن عدد الفـائزين زِيد فيها بمـا يلائم قوتها وعـالميتها ومكانتها التاريخية والاجتمـاعية والجغر افية لكان أدعى باتساع صداها، وتوافر الشعراء على المنافسة فيها. ج-جائزة دارسعاد الصباح (r): وهي جائزة قديمة تجاوز عمرها ربع قرن، لها مجالات متنوعة في الأدب وغيره، وقد فتحت في الأدب باب التنافس في مجالي: الشعر والقصة، وتميزت هذه

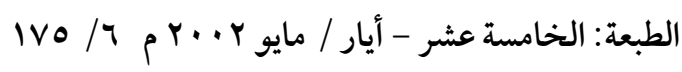

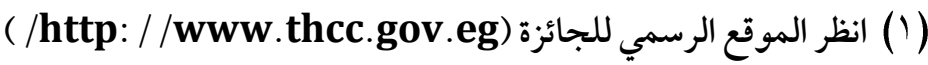
(Y) وهو منشسط ثقافي أقامته المملكة العربية السعودية تجديدا لذكرى سـوق عكاظ الذي ذاع صسيته في العصر الجاهلي، وتثــرف عليه حاليا الهيئة العامة للسـياحة وإمارة مكة المكرمة، وللمزيد انظر موقع الجائزة على الشبكة (soukokaz.sa)

$$
\text { (ار كويتية رائدة لها فرعان: علمي وأدبي، وللمزيد ير اجع موقعهم على الشبكة: }
$$

(darsouad.blogspot.com) 
المنافسة بأن جعلت التنافس في مجال القصة مقتصراً على الرواية، في حين أن أكثر المنافسات الأخرى جعلت التنافس مقتصرا على القصة القصيرة، وتسهم الدار في نشر المشاركات الفائزة تقديراً منها للفائزين. وتحصـر المنافسـة المشـاركين في فئة الشـباب فقط، وهذا ما سـارت عليه كثير من المنافسـات

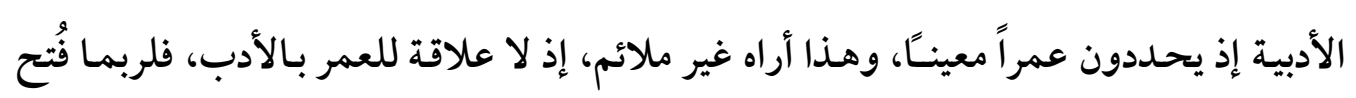
للثـاب مالم يفتح للشـيخ، وربما نضـجت القريحة بعد تقدم العمر، كما هو الحال عند النابغة الذي لم ينبغ بالثــعر إلا بعدما احتنك (()) أي حنكته التجارب وبلغ في الأمر غايته(؟)، وهذا لا يكون إلا بعد زمن طويل. ولذا قرأت في موقع الجائزة الإلكتروني تظلمات رفعها من حُرم المشاركة لكبر سنه، وطلبوا من منظمي المنافسة إعادة النظر في هذا الشرط، ولعل الذي يدفع هؤلاء المنظمين لتحديد سن مبكر رغبتهم في اكتشــاف مواهب شـابة، وهذا قصـد حسـن لكنه لايسـوغ حرمان غيرهم، ويمكن للمنظمين أن يقســموا الجائزة حسـب الفئات العمرية فيجعلوا للشـبـاب جائزة ولمن يكبرهم جائزة أخرى.

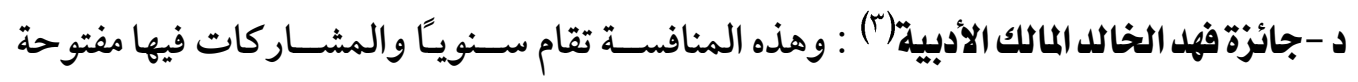
للجنسيين من كل أنحاء العالم، في الفروع التالية: الشعر، القصة القصيرة، المقالة. أما الثـعر والقصـة فقد سـبقوا إليها، وأما المقالة فإنها إضـافة مهمة للمنافسـات الأدبية، وتميز يُشاد به، والمقالة من الفنون الأدبية البارزة في العصر الحديث، والصحافة خير شاهد.

$$
\begin{aligned}
& \text { (1) (انظر : الشعر والشعر اء لابن قتيبة، تحقيق الشيخ أحمد محمد شاكر، دار المعارف - القاهرة: loV } \\
& \text { (Y) انظر : مقاييس اللغة لابن فارس، المحقق: عبد السلام محمد هارون الناشر : دار الفكر عام النشر: } \\
& 11 r / r: p / 9 V 9-81 r 99
\end{aligned}
$$

(r) جائزة سنوية تقام في مدينة عنيزة بمنطقة القصيم، ولم أجد معلومات وافية عن المنافسة ولا على من 
وحتى تكون هذه المنافسـات متميزة لا متكررة فإن على المنظمين أن يبحثوا عن الألوان الأدبية الجذابة التي تواكب الفئة المستهدفة، فإذا كانت الفئة المستهدفة شبابًا فإن الشعر الفصيح ربما لا يلائم أكثرهم؛ وذلك لأنه مقيد بوزن وقافية وصــورة وفكرة وإيحاء، أما القصسـة فهي ألأم و أفضـل، والقصــة جنس شـائع في المنافسـات الأدبية الحديثة، ولذا عمد منظمو جائزة (فهد الخالد المالك) إلى لون جديد على المنافسات الأدبية وهو المقالة. والمنتظر من هذه المنافسـات الأدبية أن تشـجع الأقلام على التزام الفصـيح والتنافس والإبداع فيه، ولذا يؤخذ على هذه المنافسـة حين سـمحت بإدخال بعض الكلمات العامية في كتابة المقالة، فقد جاء في الثــرط الرابع: أن يكون المقال باللغة العربية وتقبل بعض الكلمات العامية إذا ما استلزم السياق ذلك، مع مراعاة أن يكون محدد الأهداف والعناصر (') لن نكون بحاجة لإدخال اللهجة العامية في هذه المنافسات الأدبية؛ لأنها تخالف رسالة المنافسة وهويتها وغايتها الذي هو الاهتمام بالفصـيح، ثم إن اللغة الفصـيحة ذات مسـتويات متعددة يستطيع الكاتب أن ينزل بالمستوى أو يصعد به دون أن يخوض في اللهجة العامية. وهذه المنافسة عالمية ليست خاصة ببيئة محددة، فإذا سُمح للكلمات العامية أن تدخل فإن ذلك يستلزم وجود كلمات لا يفهمها إلا أصسحاب تلك البيئة فقط، وسـتقع لجنة التحكيم والقراء لذلك في حرج شديد، وأنى لمثل هذا القبول؟! إن التزام اللغة الفصـيحة كفيل بأن يجعل المنافســة أكثر اشـــراقـا وأبعد أثراً، حتى إذا ما أراد المنظمون لها أن يخر جوا هذه الأعمال الأدبية في مطبوعات ظهرت في صـورة حســنة تعكس الجهود المبذولة في تنظيم مثل هذه الاحتفالات الكبرى للغة العربية.

( ) نقلا عن موقع صحيفة الجزيرة السعودية (http: / /www.al-jazirah.com ) 
يتلخص مما ســق الانتشــار الواســع للمنافســات الأدبية في أرجاء الوطن العربي، وكثير من المؤسسات الرسمية والخاصة قد أخذت على عاتقها مسؤولية الاهتمام باللغة الفصحى. ورأينا من خلال عرض هذه المنافسـات الأدبية أنها شـملت أجناسـا متنوعة، وإن كان للشـعر النصيب الأوفر في ذلك، إذ كان له حضوره البارز في أغلب هذه المنافسات بأشكاله المتنوعة. والمنافسات كثيرة يصعب حصرها واستقصاؤها، ولذا وقع الاختيار على بعضها مما له إضافة على غيره، كما يغلب على هذه المسـابقات تكر ارها سـنويـا في توقيت محدد، وربما طر أ عليها شيء من التغيير عن السنة الماضية. ولا ريب أن لهذه المنافسـات أثراً طيبًا يتمثل في تشــجيع الناشـئة على العودة إلى هذه اللغة العظيمة وتذوق معانيها، حتى تعود إلى ســابق عزهـا، كما أن لهذه المنافســات أثراً طيبًا في اكتثــاف كثير من المواهب الأدبية التي لم تكن تعرف قبل ذلك، فجاءت هذه المنافســات فأبرزتْ أقلامًا راقية الأسلوب، ينتظر منها أن ينمو عودها ويشتد ساعدها لتكون نجما في سماء

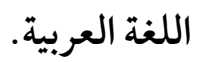
ومن آثار هذه المنافسـات الأدبية تقويم الأعمال الأدبية، إذ يتولى نقاد كبار في كل منافسـة النظر في أعمال الأدباء المتقدمين وتقويمها وإبراز محاســها، ووضـع اليد على الملاحظات النقدية، وهذا يسهم في رقي الأدب عمومـا، ويفيد منه صاحب النص خصوصـا، كما أن الأديب سيقف لاحقا على النصـوص التي نالت الجائزة ليري مواطن التميز والحسـن فيقتفي الأثر ويسـلك الطريق. هذه المنافسـات على ما فيها من محاسـن إلا أنها محدودة الأثر يكاد بعضـهـا لا يعرف منه إلا الاسم، وكثير منها لم يسمع به قط، وهذا القصور راجع إلى أسبب عديدة منها: أولاً: ضعف وسائل التحفيز: الأديب كغيره يحتاج إلى ما يدفعه نحو الإنتاج المميز، وبعض المنافسات قدمت جوائز متواضعة، وبعضها جعلت جائزتها أن يطبع ديوان الشاعر وحسب، 
وهذا المحفز المعنوي غير مجد، ويستطيع الثاعر أيا كان شعره أن يطبع منه ما شاء عن طريق دور النشر. وعليه فلا يكتفى بنثــر الديوان بل لا بد أن ينضــاف إليه غيره من المحفزات المادية والمعنوية، ليكون دافعا للإبداع الأدبي، وإذا فقد الأديب التحفيز الجيد من هذه المنافسات فأين يجده؟! ثانيا :صعوبة التواصل: الأديب بحاجة إلى تواصل مستمر مع منظمي هذه المنافسات، للرد على اسـتفسـاراتهم وسـماع آرائهم ومقترحاتهم، ليس في وقت المنافسـة فقط بل يكون التواصـل

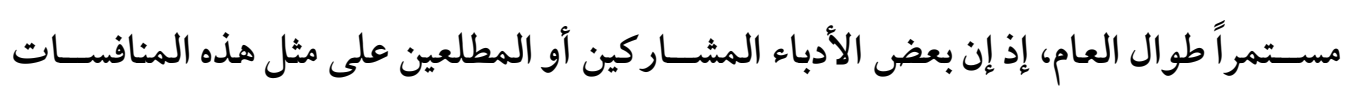
يرغبون في تطوير هذه المنافسـات وألا تكون نسـخـا متكررة، وغالبًا ما تأتي هذه المقترحات عقب نهاية كل موسم. وإذا توثقت الصـلة بين الأديب والمنظم كان ذلك ســبـا في رقي المنافســات وتوسـيع دائرة المشار كة وتميز النصوص وجودتها. ثالثاً: القيود الإضافية: كثير من المنافسات لها شروطها وقيودها؛ وذلك لضبط المشاركات وجودتها، ولتسير المنافسة وَفق الخطة المرسومة لها، إلا أن بعض الشروط أضعفت المشاركات أو حصرتها في نطاق ضيق، ومن هذه الشروط: تقييد عمر الأديب، وإن تجاوزه لا تقبل مشار كته، وهذا يجعل المنافسة محصورة في فئة قليلة ربما كانت تجربتهم الأدبية مبكرة، وفي المقابل أقفل الباب أمام من احتنكت تجاربهم، فلأي شيء حصرت المشاركات في هذا العمر؟! ومن الاشــر اطات التي لا بد أن يعاد النظر فيها تقييد المشـار كات ببلد معين أو دولمة معينة في الوقت الذي تنسب فيه الجائزة إلى مؤسسة لها حضورها المميز في العالم العربي. رابعاً: ضعف الأثر الرجعي: من أهم مقاصـد هذه المنافسـات الارتقاء بالأدب والأدباء عمومـًا، والمشــاركين خصـوصــا، ولذلك ترصسد الجوائز التي يتنافس عليها الأدباء ليخر جوا أجود ما عندهم، إلا أن ثمرة أخرى ينبغي أن تظهر وهي تقويم هذه الأعمال سـواء أفازت أم لا، وإبلاغ المتنافسـين بالملاحظات 
النقدية التي رأتها لجنة التحكيم حتى ينظر الأديب فيها ويقوّم أدبه من خلالها، ويسـتفيد منها في نصوصه القادمة. إن السـمة الغالبة على المنافسـات الأدبية ضـفف المردود النقدي لا سـيما للمشـار كات التي لم تحظ بالقبول، فلا يدري الأديب حينئذ لم رُدّت مشـار كته، ولا يعلم بالملاحظات التي سُجـلت عليه، وبهذه الفجوة يضعف أثر المنافسات الأدبية التي تقتصر على تقيم مركزي وتختم بإعلان الفائزين.

إن الناظر إلى منافســات الأدباء قديمـا يجد أن الأثر الرجعي على الأديب بارز، فالأديب يلقي

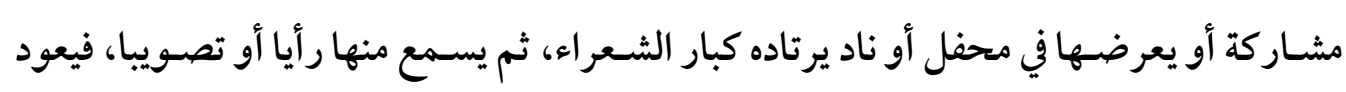
بذلك على شـعره، أو ربما سـجلت هذه المجالس اعتر اض الشـاعر على رأي الناقد وتوضسيح فكرته التي ربما لم تظهر بشكل بارز في نصه. ومن أشهر هذه المواقف النقدية ما كان في سـوق عكاظ بين النابغة وحسـان، إذ جاء الأخير بين يدي النابغة وألقي قصيدة نالت إعجابه، و كان منها: وأســـــافنـا يقطرن من نـجـدة دمـا لنـا الجفنـات الغر يلمعن بـالضـــى ومع إعجاب النابعة بهذه الأبيات إلا أنه وجّه إليه بعض الملاحظات، واقترح عليه تغيير صـيغة الجمع من السـالم (الجفنات) إلى التكسـير (الجفان) ليكون دليلا على الكثرة، وتغيير كلمة

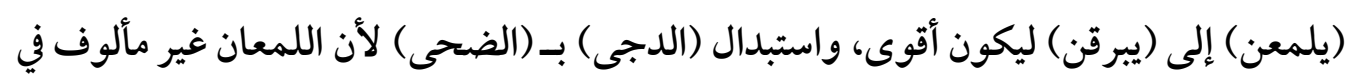

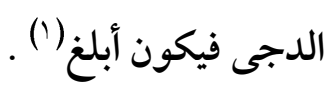
وهذا الموقف يبين الأثر القيم للنقد حين يبين للشـاعر الملاحظات التي عليه فيأحذ منها ما يراه أليق له وآنق لشعره. 
خامساً: انعدام الشراكة مع المؤسسات الإعلانية:

تعاني كثير من المنافسـات الأدبية من الانفصـال شــبه التام مع التواصـل الإعلامي لاسـيما في الإعلام الجديد، فأغلب المنافســات الأدبية -من خلال بحث وتحر - لا تملك إلا موقعها الرسمي وليس لها حسابات نشطة في مواقع التواصل الأخرى، ولا يخفى أن هذه الوسائل تعد

منصـات جماهيرية لها حضــورها الواسـع بين أوســاط المهتمين بالأدب وغيرهم وإن خروج المنافسات الأدبية في هذه المنصـات ليعد من أكبر وسـائل جذب المشـاركين، وهذا سينعكس

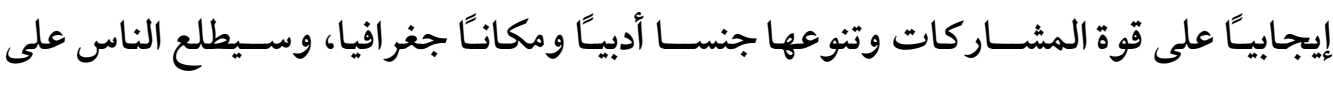
تعليمات المنافسة وشروطها وأماكن انعقادها، وغير ذلك مما يتعلق بالمنافسة . وإن مما أشعل فتيل التنافس الأدبي في التراث العربي التواصل الجيد بين وسـائل الإعلام آنذاك وبين الأدباء، ووسائل الإعلام عندهم كانت الأنصار والجماهير الذين يحيطون بالأديب، فإنهم يعملون على نشر قصائده بين أهل الموسم عامة وبين منافسي الشاعر خاصة، ليأتي الأخر فيرد عليه، وعلى إثر ذلك تذاع القصائد ويتنادى أهل الأدب للحضور والمؤازرة. سادساً: تشابه المنافسات الأدبية ؛ يغلب على هذه المنافسات التقليد والتكرار؛ إذ يركز أكثرها على الشعر والقصة، وهذان لاجرم

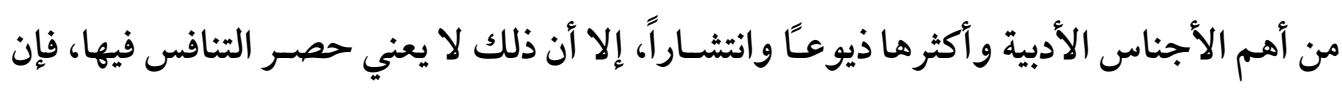
من الأجناس ما برز نجمه واتسع أثره في العصر الحديث. ومن هذه الفنون الأدبية (المسـرح) الذي كثر رواده وجماهيره لما يحتويه من الإثارة والحركة

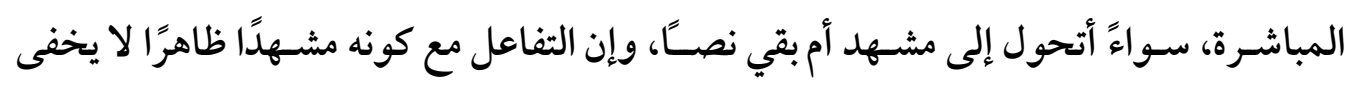
وكونه نصسًا أقرب إلى روح القصة وتفاعلاتها التي تألفها النفس وتؤثر فيها. ثم إن في التاريخ الإسـلامي مادة خصسبة للنصسوص المسـرحية يمكن للقائمين على المنافسـات الأدبية الإفادة منها، وإرشاد المهتمين للاطلاع عليها. ومن هذه الفنون التي قل الالتفات إليها في المنافسـات الأدبية (المقالة)، وهذا الفن يُعد حديثا 
من أكثر الفنون الأدبية انتشاراً حتى فاق الشعر، وحسبك أن تقر أ الصحف اليومية الإلكترونية أو الورقية لترى عدد المقالات مقارنة بالقصائد، لا أظن أن هناك تقاربا كميا، ولعل ذلك راجع إلى قلة قيود المقالة في مقابل الشعر الذي يقيده الوزن والقافية. فالمقالة لا تزال مهضــومة الجانب في منافسـاتنا الأدبية، وإن من طرق التجديد التنافسـي الأدبي توسـيع دائرة الفنون الأدبية المأثورة أو ابتكار ألوان جديدة تكون أدعى للاهتمام من قبل الأدباء

وفيما يتعلق بـالتكرار في منافســات الأدب ما تجده من آليات وضــــابط، فكثير من الآليات و الضـو ابط مكررة كأنما نسـخ بعضـها من بعض، ومن هذه الضـوابط التي تكررت تحديد سـن معين للمشــاركين أو تحديد عنوان وطني أو اجتماعي مما يضـيق فضــاء الثــاعر ويحجم لديه 


\section{القسه الثاني: (أمير الشعراء) المنافسة النموذج}

عند التأمل في واقع المنافسـات الأدبية الحالية يجد أن الضـعف والمحدودية سـمة غالبة، وهذا مما يجعل حجم تأثيرها ضــئيلا، لا يعكس مكانة اللغة وقوتها، ولا حجم الجهود والإمكانات التي تقوم عليها، وهـذا يعني أنــا بحـاجـة إلى نموذج متميز يكون مثـالا يسـهـم في الارتقــاء بالمنافسات الأخرى، وبعد استقراء للمنافسات الأدبية وقع الاختيار على (أمير الشعر اء) وهي منافسة فريدة لها تأثيرها الواسع وجمهورها الكبير. وسـميت بــــ(أمير الشـعراء) تخليدا للشـاعر المجيد أحمد شـوقي (')، الذي له مكانة بارزة بين الشعراء كما أن لمنافسة (أمير الشعراء) مكانتها بين المنافسات . وقد نشـأت هذه المنافسـة واسـتوت على سـوقها في دولة الإمارات العربية المتحدة وتحديداً في عاصمتها أبو ظبي، التي تستضيف هذه المنافسة منذ انطلاقها إلى الآن.

\section{المبحث الأول : رسم المسارووضوح الرؤية :} كثير من المنافسات الأدبية الحديثة لا تعنى برسم المسار وتحديد الغاية التي تلائم طبيعة اللغة، وهذا ينعكس سلبا على أثر المنافسة ونوعية النصوص المشاركة، أما منافسة أمير الثعراء فقد اعتمد منظموها أربعة أهداف رسمت المسار وأبانت الرؤية، هي: أولاً: النهوض بشعر العربية الفصحى والارتقاء به وبشعر ائه والترويج له في الأوساط العربية.

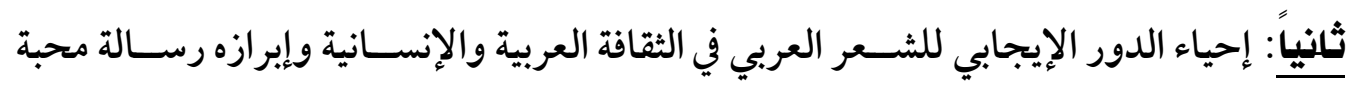

وبشير سلام.

ثاثلثا: التأكيد على دور إمارة أبو ظبي في تعزيز الثفاعل والتواصل بين شعراء العربية الفصحى في كل مكان.

رابعاً: عمل قاعدة بيانات واسعة لثسعر الفصسى وشسعر ائه ونقاده والعاملين في مجاله وعرض نتائجهم في جميع المجالات والوسائط في الوطن العربي.

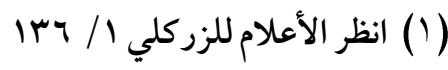




\section{المجلد السابع والثلاثون إصدار ديسمبر 19.rم م}

هذه الأهداف جاءت في الموقع الرسمي للمنافسة(')، وهي أهداف سـامية الشكل والمضسمون؛ جاءت على أهم الوظائف التي تُنتظر من مثل هذه المنافســات، ومن أهمها ما جاء في الهدف الأول الذي يعنى بنهوض الثـعر الفصـيح في زمن خبا فيه نوره وتراجعت مكانته أمام طوفان الشعر العامي والثعبي، وهذه النهضة مقرونة بالحر كة النقدية البناءة، التي لا تتأتي إلا من خلال

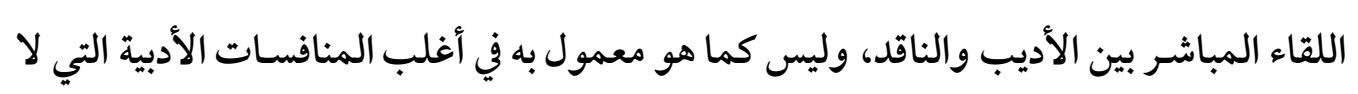

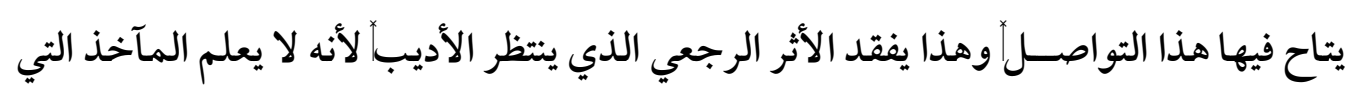
لحظها النقاد على أدبه . وقد نص الهدف الأول على الترويج للشـاعر وتعريف الجمهور بها وذلك من خلال قناة أبوظبي التي تعد ناقلا حصريًا لهذه المنافسة، كما أن الترويج للشاعر يتخذ شكلا آخر من خلال شبكة الإنترنت، إذ تذاع حلقات المنافسة مسجلة على برنامج (youtube) وقد بلغ عدد المشاهدات لإحدى الحلقات أكثر من مائة ألف مثـاهدة!! وهذا يبرز لنا ضـرورة عناية المنافسـات الأدبية بهذه البرامج، التي تعد وسيلة مهمة لإيصال الأدب العربي إلى العالم.

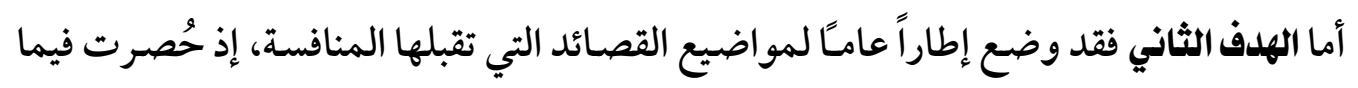
يؤكد دور الشعر الإيجابي الذي ينشر الخير والمحبة وينبذ التعصب والكراهية، وهذا الهدف لا يحد من مســاحة الاختيار أمام الشـاعر، بل إن له أن ينظم ما شــاء مما تفيض به قريحته واصـفـًا

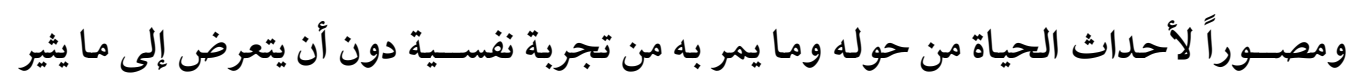
الأحقاد أو يوغر الصدور.

وفي هذا الشرط رسالة ضمنية إلى الشعراء وأهل الأدب تبين سمو الكلمة وعلو شأنها وما ينبغي أن يصرف القول فيه، لا سيما في وقت أوقد فيه بعض الشعراء نار النعرات والعصبيات. أما الهلدف الثالث ففيه إبراز الدور الإقليمي لأبو ظبي التي يراد لها من هذه المنافسة أن تكون منبرا للغة ومعلمًا للأدب، يرتادها الشعراء من أصقاع بعيدة، ومنها يصل صوتهم إلى العالم.

( انظر الموقع الرسمي للمنافسة (/http: / / www.princeofpoets.com ) 


\section{المنافسات الأدبية الحديثة وأثرها على الحركة الأدبية}

أما اللهدف الرابع فهو الأثر الرجعي الذي يميز هذه المنافســة عن غيرهاّ ويوسـع حجم تأثيرها الأدبي من خلال عمل قاعدة بيانات واسـعة تجمع فيها مشـاركات الأدباء والنقاد من داخل المنافسـة وخارجها، وتشـمل قاعدة البيانات كل شـعراء الفصـحى ونقاده، وبعد الجمع تأتي مرحلة النشـر الذي صـار متاحسا عبر الوسـائط الحديثة، إذ يتسـى لكل مهتم بالأدب أن يجد بين يديه ما يبحث عنه من شعر ونقد في فترة وجيزة بفضل سرعة محر كات البحث في هذه الوسائط الإلكترونية، ولعل مما يميز هذه القاعدة أنها ستضم مشاركات كثير من الأدباء صوتـاّوصورة، ولا ريب أن اسـتماع القصـيدة من قائلها مباشـــة أشـــــأثيرا؛ لأنه لسـان القصـيدة الذي عالج أحداثها ورصف كلماتها .

\section{المبحث الثاني : القيود المحكمة:}

لكل منافسـة قيود تحكم على ضسوئها المشـاركات، وهي ركيزة أسـاسية للبناء الصسحيح؛ لأنها تحدد مسـار المشـاركات، وبناء عليها يتم التقييم والقبول أو الرد، ومنافسـة (أمير الشـعراء) قد

$$
\text { رسمت لنفسها قيودا ضوابط رفعت من شأنها، وهي: }
$$

أولاً: تكون المشاركة مقصورة على القصائد المكتوبة باللغة العربية الفصحى. ثانياً : تكون المشار كة مقصورة على شعر الفصحى العمودي التقليدي والشعر الحر أو التفعيلة

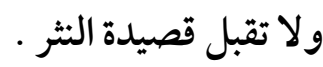
ثالثاً : المشاركة مفتوحة للشعراء من سن الثامنة عشرة إلى سن الخامسة والأربعين فقط . رابعاً : سوف تكون دولة الإمارات وإمارة أبو ظبي مركز التنفيذ الفني للبرنامج · خامساً: : سـيشـارك الثـعراء في مراحل متتابعة من المنافسـات المتنوعة والتصـفيات أمام لجنة تحكيم مختارة .

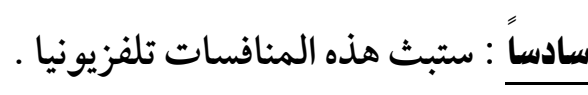
سـابعاً : تبدأ المشاركة بأن يرسل الثاعر من أشعاره قصيدة عمودية واحدة في حدود (عشرين خمسـة وعشرين) بيتًا، أو قصيدة واحدة من شعر التفعيلة ( الشعر الحر ) لا تزيد عن مقطعين 
كل واحد منها في حدود (خمسة عشر ) سطراً .

ثامناً : يرسل الشاعر مع قصيدة سيرة ذاتية أدبية مختصرة . تاسعاً : سيفوز في نهاية البرنامج خمسة شعر اء، وستكون جوائزهم على النحو الآتي : المركز الأول : لقب أمير الشـعراء إضـافة إلى مليون درهم إماراتي إضـافة إلى ميدالية ذهبية إضـافة إلى وشاح بشعار المهرجان إضافة إلى شهادة فوز إضافة إلى طبع ديوان له مسموع ومقروء . المركز الثاني : خمسمائة ألف درهم إماراتي وبقية الجوائز كالأول دون اللقب والميدالية فضية. المركز الثالث : ثلاث مئة ألف درهم إماراتي وبقية الجوائز كالمركز السابق، والميدالية برونزية. المركز الرابع : مائتا ألف درهم إماراتي وبقية الجوائز كالمركز السابق . المركز الخامس : مائة ألف درهم إماراتي وبقية الجوائز كالمركز السابق . ومن نظر في هذه الضـوابط المحكمة وجدناها متسـقة مع الأهداف التي قامت عليها المنافسـة، ففي الشرط الأول قيدت المشـاركات بالشـعر الفصسيح، ثم فتحت المجال في الشـرط الثاني، فلم تقيده باللون التقليدي للشـعر (العمودي) إنما فتحت المجال للشـعر اء أن ينظموا في نوعي الشعر : العمودي والتفعيلة. ويلحظ في الشرط الثاني أنهم استبعدوا ما يسمى بـ (قصيدة الثثر)؛ لأنها لا تحمل أهم خصائص الثعر التي تميزه عن الكلام العادي وهي الوزن والقافية، فهي أقرب إلى الثر، ولذا استبعدت من المنافسة (') (1) (2) أما ال ش شرط الثالث فإنه حدد معيار السـن، إذ قيده من سـن الثامنة عثــرة إلى سـن الخامسـة والأربعين، وهذا يعني أن المجال متاح لثـريحة كبرى من الشـعراء من أول الثـباب إلى سـن

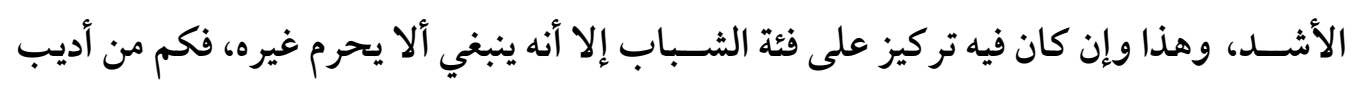
لازال شعره دفاقا لم ينضب وقد جاوز الأربعين. أما الـشرط الرابع فإنه حدد الإطار المكاني الذي تقام فيه المنافسـة، وهذا أمر معتاد في منافسـات (1) انظر : قضايا الشعر المعاصر، نازك الملائكة، الناشر : دار العلم للملايين، -بيروت الطبعة: الخامسة: 10 


\section{المنافات الأدبية الحديثة وأثرها على الحرهح الأديية}

الأدب أن يحدد الإطار الزماني والمكاني، وهو حق مشروع لمنظمي المنافسة والمشرفين عليها، ولذا فإن إمارة أبو ظبي تتكفل بنقل المتنافسـين إليها وتأمين سـكن مناسـب لهم، منذ المر احل الأولية وحتى نهاية المنافسة. أما الشرط الخامس فإنه مما يميز هذه المنافسـة عن غيرها، وهو أن الشـاعر سيمر على مجموعة من المر احل المتنوعة أمام لجنة التحكيم، ولكل مرحلة هذه المر احل طبيعة مختلفة. إذا فالشاعر لن يشارك بقصيدة واحدة بل بعدة قصائد وبألوان مختلفة، وأكثر المنافسات الأدبية الأخرى يشـارك فيها الأديب بنص واحد ربما لا تظهر فيه شـاعريته؛ لأنه محاط بمجموعة من القيود في الموضوع والحجم والشكل، وإذا كثرت القيود خبت جذوة الإبداع. 


\section{نتائجوتوصيات}

من أبرز النتائج التي خرجت بها هذه الدراسة :

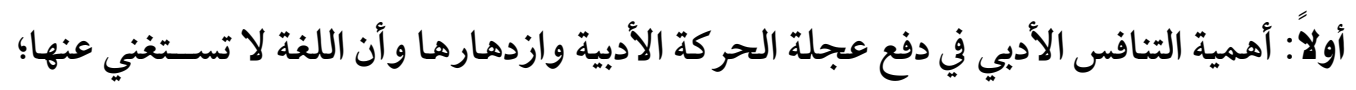

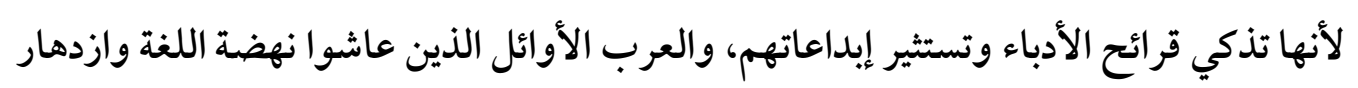

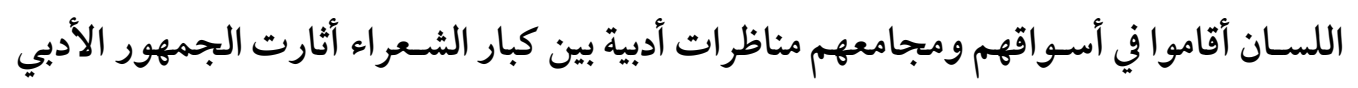

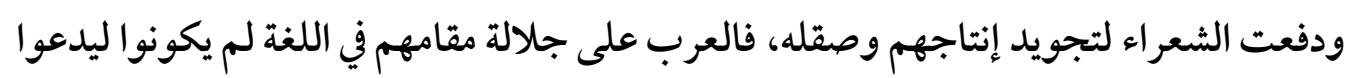

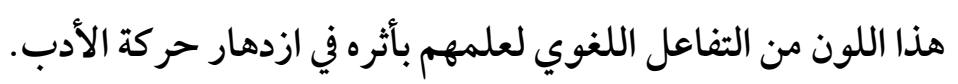

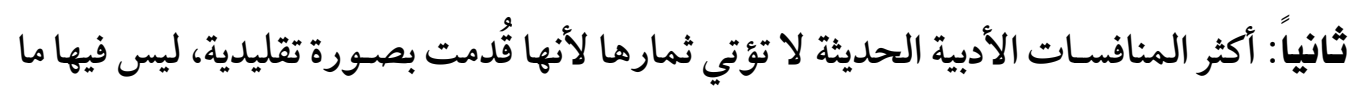
يثير قريحة الأديب أو ما يحفزه لإخراج أجود ما ألنده.

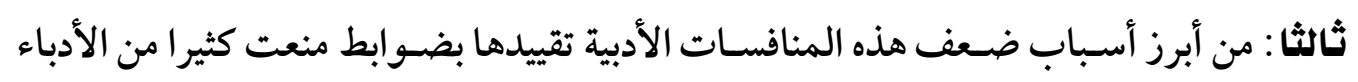
من المشاركة فيها، كاشتراط سن معين أو مجموعة كبيرة من القصائد.

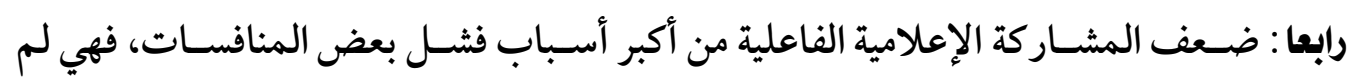
تنشئ مواقع للتواصل المباشر الفاعل بين الأديب وأعضاء المنافسة.

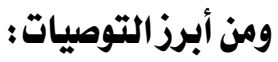
أولا: لا ينبغي التركيز على لون واحد من الأدب في المنافسات الأدبية؛ لأن للناس مشارب شتى

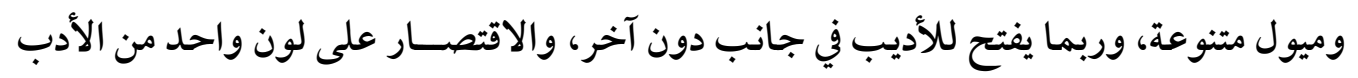
يحرم كثيرين من المنافسة. ثانيا: العناية في المنافسات بالألوان الأدبية الحديثة مثل الخواطر القصيرة، وتحليل المضمون

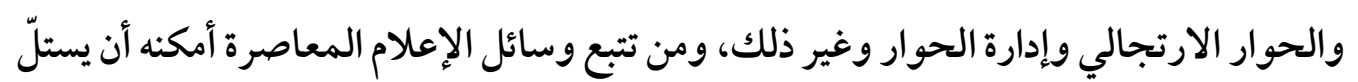
منها ألوانًا أدبية بهية جديرة أن يكون لها حضور في المنافسات الأدبية.

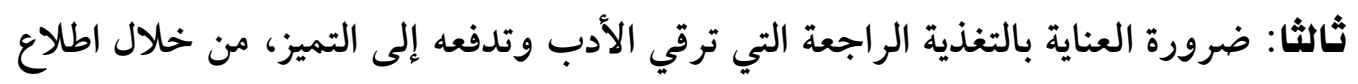
المتنافسين على أبرز الملاحظات النقدية التي أضعفت نتاجهم. رابعا: رصد الحوافز المشجعة؛ لكونها من أهم سمات المنافسة المتميزة، لذا على القائمين

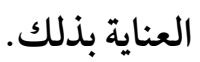




\section{قائمة المصادروالمراجع}

أولا : الكتب:

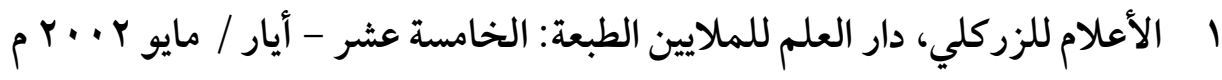
r

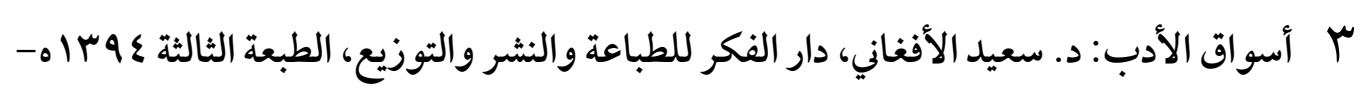
pl9v

ع البداية والنهاية لابن كثير، تحقيق د. عبد المحسن التركي، دار هجر، الطبعة الأولى ^ | \ـ اهـ

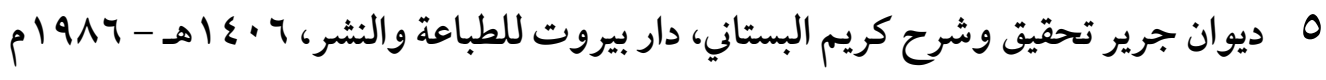

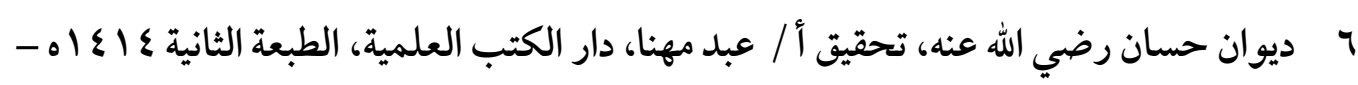
p $199 \varepsilon$

V ديوان الخنساء اعتنى به وشرحه حمدو طماس، دار المعرفة، بيروت- لبنان، الطبعة الثانية،

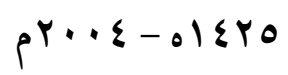

^ ربيع الأبرار ونصوص الأخيار للزمخشري، الناشر: مؤسسة الأعلمي، بيروت الطبعة:

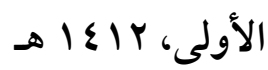

q سير أعلام النبلاء للذهبي، مجموعة من المحققين بإشراف الشيخ شعيب الأرناؤوط،

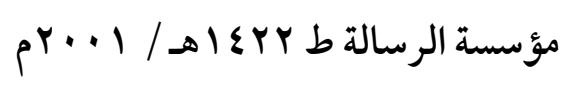

• الشعر والشعر اء لابن قتيبة، تحقيق الشيخ أحمد محمد شاكر ، دار المعارف - القاهرة

ا الصحاح للجوهري، تحقيق أحمد عبدالغفور عطّار دار العلم للملايين الطبعة الثالثة ـ

Y ا ضحى الإسلام لأحمد أمين، من مطبوعات الهيئة العامة المصرية للكتاب: طبع سنة ب +. ب م ب ا قضايا الشعر المعاصر، نازك الملائكة، الناشر : دار العلم للملايين، -بيروت الطبعة: الخامسة 
ع ا معجم العين، للخليل بن أحمد تحقيق وترتيب د. عبد الحميد هنداوي، دار الكتب العلمية-

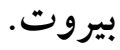

10 مقاييس اللغة لابن فارس، تحقيق الشيخ عبد السلام محمد هارون الناشر: دار الفكر عام

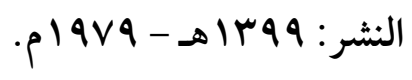

7 ا الموشح، للمرزباني، تحقيق محمد حسين شمس الدين، دار الكتب العلمية-بيروت، الطبعة

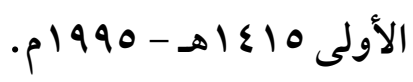

ا وفيات الأعيان لابن خلكان، المحقق: إحسان عباس الناشر : دار صادر - بيروت.

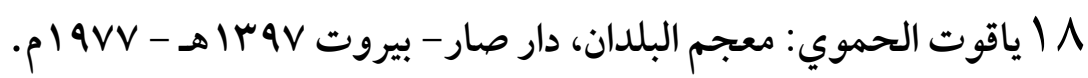

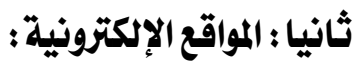

$$
\text { موقع (mawdoo3.com) }
$$

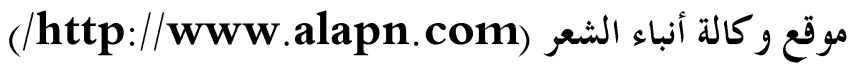

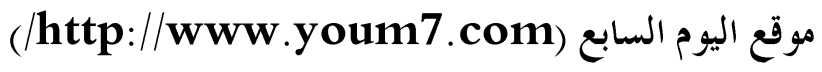

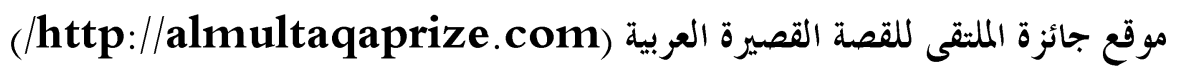

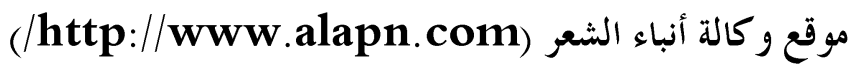

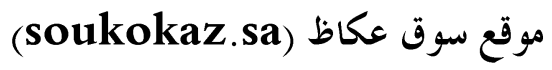

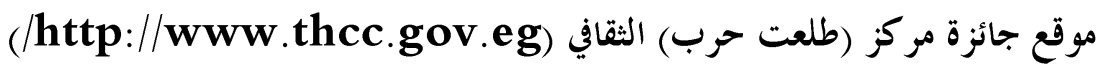

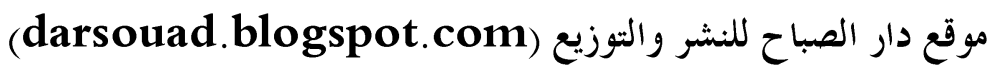

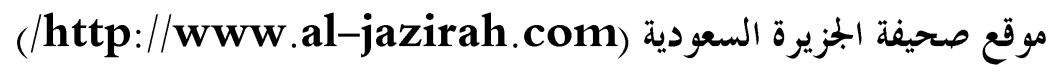

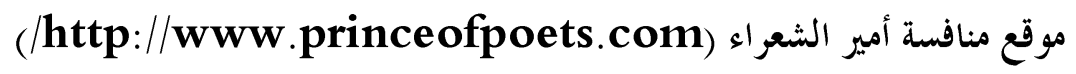


المنافسات الأدبية الحديثة وأثرها على الحركح الأديية

فهرس البحث

\begin{tabular}{|c|c|c|}
\hline الصـفحة & المــــوفوع & مـ ( ما \\
\hline r६וץ & 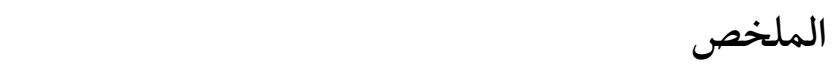 & 1 \\
\hline$r \leqslant 10$ & 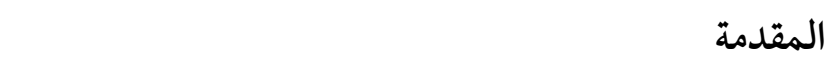 & r \\
\hline rะ19 & التمهيد: نبذة عن المنافسات الأدبية قديما. & $r$ \\
\hline rEYY & القسم الأول: المنافسات الأدبية الحديثة: & $\varepsilon$ \\
\hline rEYY & المبحث الأول: المنافسات ذات الجنس الأدبي الواحد: & 0 \\
\hline T\&YY & جائزة جمعية علي بن غذاهم & 7 \\
\hline rEYY & جائزة الشاعر أسامة الدناصوري & $\checkmark$ \\
\hline TEYY & جائزة الملتقى للقصة القصيرة العربية & $\wedge$ \\
\hline rEYA & جائزة البيت الثقافي للكتابة القصة القصيرة (الومضة) & 9 \\
\hline rEYA & المبحث الثاني: المنافسات ذات الأجناس الأدبية المشتر كة & 1. \\
\hline rEYA & جائزة مركز (طلعت حرب) الثقافي & 11 \\
\hline rera & جائزة سوق عكاظ & ir \\
\hline rerq & جائزة دار سعاد الصباح & ir \\
\hline rst. & جائزة فهد الخالد المالك الأدبية & 18 \\
\hline retr & المبحث الثالث: نظرة ناقدة لهذه المنافسات الأدبية & 10 \\
\hline rदTr & أولاً: ضعف وسائل التحفيز & 17 \\
\hline retr & 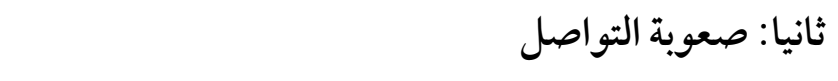 & iv \\
\hline rerr & ثالثًا: القيود الإضافية & M \\
\hline rßrt & رابعـا: ضعف الأثر الرجعي & 19 \\
\hline reto & خامستًا: انعدام الشر اكة مع المؤسسات الإعلانية & r. \\
\hline
\end{tabular}


المجلد السابع والثلاثون إصدار ديسمبر 19. Prم ي.

\begin{tabular}{|c|c|c|}
\hline TETo & سادستً: تشابه المنافسات الأدبية & M \\
\hline rerv & القسم الثاني: (أمير الشعر اء) المنافسة النموذج & $r r$ \\
\hline rerr & المبحث الأول: رسم المسار ووضوح الرؤية & $r r$ \\
\hline rदra & المبحث الثاني: القيود المحكمة & Y \\
\hline røsץ & نتائج وتوصيات & ro \\
\hline rşr & قائمة المصادر والمر اجع & ry \\
\hline rs\&o & فهرس الموضوعات & rr \\
\hline
\end{tabular}

